\title{
Prymas Stefan Wyszyński WOBEC RZECZYWISTOŚCI SPOŁECZNO-POLITYCZNEJ PRL 1974-19781
}

Słowa kluczowe: prymas Stefan Wyszyński, system komunistyczny, rzeczywistość polityczna, relacje państwo-Kościół, Edward Gierek, społeczeństwo, opozycja.

Ke y w o rd s: primate Stefan Wyszynski, communism system, political reality, church and state relations, Edward Gierek, political opposition.

\section{SUMMARY}

In the seventies, Cardinal Stefan Wyszyński was not only the undisputed leader of the Polish Church, but also a widely respected authority in society, whose voice was

1 Poniższy tekst jest kontynuacją rozważań autora podjętych w artykule: Prymas Wyszyński wobec pozornej normalizacji relacji państwo-Kościót pierwszych lat rządów Edwarda Gierka (1971-1974), ,Politeja” 2019 nr 60, w druku. Na temat kard. Wyszyńskiego powstało już wiele prac. Wspomnieć należy przede wszystkim o próbach ujęć biograficznych: A. Micewski, Kardynał Wyszyński, prymas i mąż stanu, Paryż 1982; P. Raina, Stefan Kardynat Wyszyński Prymas Polski, t. 1-3, Londyn 1979-1988; idem, Kardynał Wyszyński, t. 1-14, Warszawa 1994-2007; M.P. Romaniuk, Życie twórczość i postuga Stefana Kardynała Wyszyńskiego Prymasa Tysiąclecia, t. 1-4, Warszawa 1994-2002; E. Czaczkowska, Kardynat Wyszyński. Biografia, Kraków 2013; R. Łatka, B. Mackiewicz, D. Zamiatała, Kardynał Stefan Wyszyński 1901-1981, Warszawa 2019 (tam też najnowsze zestawienie literatury dot. prymasa Wyszyńskiego). 
of great importance. In the above analysis, the attitude of the „Primate of the Millennium" to the socio-political reality of the PRL was discussed. A comprehensive view of this hierarch was presented regarding the functioning of the communist system in Poland; his approach to the state-church relationship; to key political events (amendment to the constitution, events of June 1976, election of Cardinal Wojtyła as pope) and attitude to the rise and activity of the pre-August opposition. This analysis does not aspire to the full exhaustion of the topic, it focuses on issues most for Cardinal Wyszyński important in the socio-political sphere.

\section{STRESZCZENIE}

Kardynał Stefan Wyszyński był w latach siedemdziesiątych nie tylko niekwestionowanym liderem polskiego Kościoła, ale również powszechnie szanowanym w społeczeństwie autorytetem, którego głos miał duże znaczenie. W powyższej analizie omówiono stosunek „Prymasa Tysiąclecia” do rzeczywistości społecznopolitycznej PRL. Przedstawiono całościowe spojrzenie tego hierarchy dot. funkcjonowania systemu komunistycznego w Polsce (w latach 1974-1978); jego podejście do relacji państwo-Kościół; do kluczowych wydarzeń politycznych (nowelizacja konstytucji, wydarzenia z czerwca 1976, wybór kard. Wojtyły na papieża) oraz stosunku do powstania i działalności opozycji przedsierpniowej. Wspomniana analiza nie aspiruję do pełnego wyczerpania tematu, skupia się na kwestiach najbardziej dla kard. Wyszyńskiego istotnych w sferze społeczno-politycznej.

\section{Wprowadzenie}

Tardynał Stefan Wyszyński odgrywał w rzeczywistości PRL lat siedemdzie- Lsiątych ważną rolę. Jego autorytet był powszechnie uznawany nie tylko w Kościele i społeczeństwie, ale również przez władze Polski „ludowej” na czele z Edwardem Gierkiem. Pierwszy sekretarz KC PZPR w raz z biegiem lat uświadomił sobie, że tradycyjne metody zwalczania Kościoła i jego prymasa nie przynoszą efektów. $Z$ tego też powodu wdrożył politykę reglamentowanej normalizacji, która polegała na stwarzaniu dobrej atmosfery stosunków wzajemnych, ale bez ustępstw w kluczowych dla Kościoła sprawach². Prymas miał

${ }^{2} \mathrm{Na}$ temat relacji państwo-Kościół w latach siedemdziesiątych XX w. powstała już dość obszerna literatura, ciągle brakuje jednakże całościowej monografii. Wśród najważniejszych prac należy wspomnieć o: A. Dudek, Lawirowanie. Ekipa Gierka wobec Kościoła katolickiego (1971-1978), „Więź” 1997 nr 7, s. 125-152; J. Żaryn, Dzieje Kościoła kato- 
pełną świadomość koniunkturalności działań władz partyjno-państwowych, ale uważał, że E. Gierek to najlepsza z najgorszych opcji, gdyż każdy kolejny I sekretarz KC PZPR będzie dla interesów Kościoła i społeczeństwa wyborem o wiele mniej korzystnym ${ }^{3}$. Jego optykę potwierdziły ustępstwa komunistów w zakresie nowelizacji konstytucji, amnestii dla uczestników wydarzeń Czerwca 1976 r., czy też w późniejszym okresie zgody na papieską pielgrzymkę w $1979 \mathrm{r}^{4}$.

Kardynał Wyszyński w drugiej połowie dekady Gierka wielokrotnie odnosił się do spraw społeczno-politycznych. Zabierał głos zarówno publicznie, $\mathrm{w}$ homiliach kierowanych do wiernych, jak i korespondencyjnie w listach i memoriałach wysyłanych do władz (zarówno w formie wypracowanego przez Episkopat Polski stanowiska jak i osobistych pism do poszczególnych dygnitarzy partyjnych). Najważniejszymi jednak materiałami źródłowymi pozwalającymi odtworzyć stosunek prymasa do rzeczywistości społeczno-politycznej PRL są jego zapiski osobiste Pro memoria ${ }^{5}$ oraz dokumentacja

lickiego w Polsce (1944-1989), Warszawa 2003, s. 293-418; K. Pawlicka, Polityka władz wobec Kościoła katolickiego(grudzień 1970- październik 1978), Warszawa 2004; A. Dudek, R. Gryz, Komuniści i Kościół w Polsce (1945-1989), Kraków 2006, s. 277-349; K. Maniewska, Kościót katolicki w Bydgoszczy wobec prób laicyzacji i dezintegracji społeczeństwa w okresie rządów Edwarda Gierka (1970-1980), Warszawa 2007; R. Gryz, Między liberalizacja a dezintegracją. Stosunki państwo-Kościół w latach siedemdziesiątych [w:] Stosunki państwo-Kościół w Polsce w latach 1944-2010. Studia i materiały, red. R. Łatka, Kraków 2013, s. 73- 92; idem, Kierunki polityki wyznaniowej w dekadzie Gierka [w:] Priorytety polityki wyznaniowej władz Polski ,ludowej”, red. R. Eatka, „Glaukopis” 2015 nr 33, s. 286-306; R. Łatka, Episkopat wobec złudnej normalizacji relacji państwo-Kościół 1971-1978 [w:] Dzieje Kościoła katolickiego na Pomorzu Zachodnim w latach 1972-1978, red. M. Siedziako, Z. Stanuch, G. Wejman, Szczecin 2018, s. 57-86. Zob. również, Plany pracy Departamentu IV MSW na lata 1972-1979, oprac. M. Biełaszko, A. Piekarska, P. Tomasik, C. Wilanowski, Warszawa 2007. Por. z dokumentacja UdsW z tego okresu, A. Friszke, PRL wobec Kościoła. Akta 1970-1978, Warszawa 2010.

3 Analogicznie uważał Jan Paweł II, który podkreślił to w czasie I pielgrzymki do ojczyzny. Zob. szerzej, Protokót Rady Głównej Episkopatu Polski, 5 VI 1979, Jasna Góra [w:] Sprawy, które toczq się w Polsce majq znaczenie światowe. Niepublikowane przemówienie Jana Pawła II do Rady Głównej Episkopatu Polski, Jasna Góra, 5 czerwca 1979 r., red. A. Grajewski, Jasna Góra 2019, s. 37.

4 Zob. szerzej, R. Łatka, Episkopat Polski wobec stosunków państwo-Kościół i rzeczywistości społeczno-politycznej PRL 1970-1989, Warszawa 2019, s. 256-333.

5 Archiwum Archidiecezji Gnieźnieńskiej (dalej: AAG), S, Wyszyński, Pro memoria 1974-1978. 
Episkopatu Polski pochodząca ze zbiorów Sekretariatu Prymasa Polski zgromadzona w Archiwum Archidiecezjalnym Warszawskim ${ }^{6}$. To właśnie ta dokumentacja, uzupełniona o analizę homilii kard. Wyszyńskiego ${ }^{7}$ i istniejącą literaturę przedmiotu będzie podstawą poniższej analizy.

Tekst został podzielony na kilka części. W pierwszej z nich omówiono spojrzenie prymasa na misję Kościoła w rzeczywistości społeczno-politycznej PRL z uwzględnianiem jego uwag generalnych dot. systemu komunistycznego w polskich realiach ${ }^{8}$; w kolejnej syntetycznie ujęto podejście kardynała do relacji państwo-Kościół; dwa następne wydzielone fragmenty dot. stosunku hierarchy do ważnych wydarzeń politycznych (nowelizacji Konstytucji PRL i Czerwca 1976 r.); w tekście opisano również stosunek prymasa do opozycji przedsierpniowej; rozmowy z Edwardem Gierkiem z października 1977 r. oraz do wyboru kard. Wojtyły na papieża ${ }^{9}$. Poniższe rozważania nie aspirują do wyczerpania podejmowanego tematu, który w przekonaniu autora wyma-

6 Archiwum Archidiecezjalne Warszawskie, Sekretariat Prymasa Polski (dalej: AAW, SPP) 04/29-34, Rada Główna Episkopatu Polski 1974-1980; AAW, SPP 04/269-294, Konferencje Plenarne Episkopatu Polski 1974-1978.

7 Obejmuję ona również dotychczas niepublikowane autoryzowane przemówienia prymasa Wyszyńskiego zgromadzone w zasobie Archiwum Instytutu Prymasowskiego Stefana Kardynała Wyszyńskiego w Choszczówce (dalej: AIPSKW).

8 Stosunkowi prymasa Wyszyńskiego do systemu komunistycznego poświęciłem osobne studium: Czy Prymas Polski Stefan Wyszyński był antykomunistą? [w:] Antykomunizm Polaków w XX wieku, red. P. Kardela, K. Sacewicz, Białystok-Olsztyn-Warszawa 2019, s. 569-592. Na ten temat zob. także, P. Skibiński, Do jakiego stopnia PRL byt państwem polskim? Ocena prymasa Wyszyńskiego, [w:] Prymas Stefan Wyszyński a Niepodległa. Naród patriotyzm - państwo w myśli i nauczaniu Prymasa Tysiąclecia, red. E. Czaczkowska, R. Łatka, Warszawa 2019, s. 77-88.

9 Poniższa analiza nie obejmuję tematu stosunku prymasa Wyszyńskiego do gry prowadzonej przez władze PRL ze Stolicą Apostolską. Autor przygotował na ten temat osobne studium, które ukaże się w 2020 r. Na ten temat zob. A. Dudek, PRL i Stolica Apostolska 1971-1974, [w:] Społeczeństwo - Państwo - Kościót 1945-2000. Materiały z ogólnopolskiej konferencji naukowej. Szczecin 15-16 VI 2000 r., red. A. Kawecki, K. Kowalczyk, A. Kubaj, Szczecin 2001, s. 48-53; P. Raina, Arcybiskup Dąbrowski - rozmowy watykańskie, Warszawa 2001; idem, Cele polityki władz PRL wobec Watykanu, Warszawa 2001; A. Grajewski, Kardynałowie Stefan Wyszyński i Agostino Casaroli - dwie osobowości i dwie koncepcje polityki wschodniej Watykanu, „Studia Prymasowskie” 2009 (t.3), s. 51-80; P. Skibiński, Cele polityki władz komunistycznych w Polsce wobec Stolicy Apostolskiej do roku 1978, [w:] Priorytety polityki..., s. 333-346; R. Łatka, Episkopat Polski..., s. 183-254. 
ga dalszych pogłębionych badań (chociażby w zakresie opisu nauczania kard. Wyszyńskiego do różnych grup społecznych), nakreślają jednakże stosunek prymasa do kluczowych zagadnień ze sfery społeczno-politycznej ${ }^{10}$.

\section{Misja Kościoła i uwagi generalne o systemie komunistycznym}

Stefan Wyszyński, posiedzenie Rady Głównej Episkopatu Polski z 10 III 1975:

[...] możemy przegrać z państwem, z rzq̨dem, z partia, ale nie możemy przegrać z Narodem. To my czujemy, co się dzieje w duszy Narodu ${ }^{11}$.

Kardynał Wyszyński w latach 1974-1978 kilkukrotnie odnosił się w szeroki i pogłębiony sposób do funkcjonowania systemu komunistycznego w PRL. Jego uwagi świadczyły o tym, że posiadał rozbudowaną wiedzę zarówno na temat mechanizmów sprawowania władzy w rzeczywistości politycznej Polski „ludowej” oraz celów komunistów w zakresie polityki społecznej. Prymas miał także świadomość, że rząd PRL nie ma zamiaru rezygnować z realizacji swoich ideologicznych zamierzeń. Jasno podkreślał to w czasie swojej rozmowy z abp. Luigi Poggim stałym delegatem Stolicy Apostolskiej do rozmów z władzami Polski, która odbyła się 28 lutego w Gnieźnie: „Delegacja robocza musi sobie

${ }^{10}$ Co istotne tekst nie obejmuję opisanej już dość wyczerpująco kwestii podejścia i polityki władz do działalności „Prymasa Tysiąclecia”. Na ten temat zob. W służbie Boga i Polski. Komunistyczna bezpieka wobec kardynała Stefana Wyszyńskiego, oprac. J. Marecki, P. Nitecki, R. Szczypta-Szczęch, Kraków 2014 (tam też pełna literatura przedmiotu). Kluczowa jest w tym zakresie zmiana optyki jaka dokonała się jesienią 1975 r. Miejsce kard. Wyszyńskiego jako jednego z głównych przeciwników władz zajął kard. Karol Wojtyła nazywany przez ministra-kierownika UdsW Kazimierza Kąkola „intelektualistą awanturnikiem”. Zob. szerzej, A. Dudek, Prymas Stefan Wyszyński wobec władz komunistycznych w latach 1956-1978 [w:] Prymas Stefan Kardynat Wyszyński - świadek Ewangelii i tradycji narodowych. Materiały sesji naukowej w Wyższym Seminarium Duchownym w Kielcach 19 maja 2001 r., Kielce 2001, s. 53-54. Por. Charakterystyka działalności kard. Karola Wojtyty w latach 1964-1976, 15 XI 1976 [w:] Teczki Wojtyty, Warszawa 2003, s. 428-432.

11 AAW, SPP 04/30, Rada Główna Episkopatu Polski 1975, k. 22, Protokół KGEP z 10 IIII 1975, Warszawa. Analogiczne dzień później prymas skierował również do wszystkich biskupów, w czasie obrad plenarnych, AIPSKW, S. Wyszyński, Kazania i przemówienia autoryzowane, t. XLIX, „Rozmowy «Kościół-Państwo» na etapie obecnym”. Wypowiedź Prymasa Polski na 147 Konferencji Plenarnej Episkopatu Polski, 11 III 1975, Warszawa. 
zdawać sprawę z tego, że ma do czynienia z odmiennym rozmówcą. Przecież nasi komuniści nie wyrzekną się walki ideologicznej z Kościołem, z religią i nie wyrzekną się ateizacji, dialektyki mat[erialistycznej] i laicyzacji; nie przyznają Kościołowi statusu publiczno-prawnego"12.

Zdaniem kard. Wyszyńskiego misja Kościoła w latach siedemdziesiątych nie różniła się od tej z poprzednich, choć była realizowana nieco innymi metodami (nie było chociażby aż tak rozbudowanego programu duszpasterskiego jak w przypadku „Wielkiej Nowenny”) ${ }^{13}$. Prymas uważał, że polega ona na obronie polskiej racji stanu ${ }^{14}$, co wskazał w kazaniu wygłoszonym w Krakowie 11 maja 1975 r: „Kościół, dzieci Boże, w naszej ojczyźnie staje, za wzorem swoich najwyższych pasterzy, w obronie człowieka przed nadużyciami ze strony władzy. I dlatego też i w Polsce Kościół staje w obronie - że się tak wyrażę - narodowej racji stanu, co oznacza coś więcej aniżeli polityczna racja stanu, bo polityczna racja stanu zmienia swoje wymiary, natomiast naród trwa, ma swoją kulturę religijną, narodową, swój obyczaj narodowy i stoi na straży tych wartości, które od razu nie powstają, ale też i zniszczyć się od razu nie dadzą"15. Kardynał Wyszyński zdecydowanie podkreślał, iż „Sytuacja w jakiej znajduję się nasza Ojczyzna, wymaga od nas przyznawania i wyznawania wiary przed ludźmi oraz domagania się wolności mówienia prawdy"16. Prymas w swoich zapiskach bezpośrednio (i wielokrotnie) wskazywał na bliskie związki Kościoła i Narodu: „W Polsce nie istnieje stosunek Dwóch: Kościół i Państwo. Bo jest to baza jurydyczna. - W Polsce jest trójkąt: Kościół-Państwo-Naród. [...] Jeśli pisano w prasie polskiej o trójkącie - Kościół - Pań-

12 AAG, S, Wyszyński, Pro memoria 1975, zapis z 28 II 1975.

${ }^{13} \mathrm{Na}$ temat założeń i realizacji „Wielkiej Nowenny” zob. szerzej, J. Zawadka, Wielka Nowenna w koncepcji duszpasterskiej prymasa Wyszyńskiego. Zarys problematyki pastoralno-historycznej, „Warszawskie Studia Teologiczne” 2011 nr 1, s. 243-254; B. Noszczak, My Naród. Polska i Polacy w milenijnym programie prymasa Stefana Wyszyńskiego (1956-1966/1967) [w:] Prymas Wyszyński a niepodległa..., s. 153-188.

${ }_{14} \mathrm{Na}$ ten temat zob. szerzej, R. Eatka, The idea of the common good and the reason of state in the teaching of primate Wyszyński, „Studia Theologica Varsaviensia” 2018 nr 2, s. $65-82$.

15 Cyt. za J. Żaryn, Dzieje Kościoła..., s. 378.

Zob. także,

16 S. Wyszyński, Trzy wieżyce nad Polską, 9 V 1976, Kraków [w:] idem, Z królewskiego Krakowa, Warszawa 1992, s. 63. 
stwo i Episkopat, to ten bok trójkąta - «Episkopat» równa się - Naród. To znaczy - Episkopat, mający oparcie w Narodzie ${ }^{17 "}$.

Zagadnienia te prymas poruszył także w trzecim cyklu Kazań Świętokrzyskich, wygłoszonych na początku 1976 r. $^{18}$, np. 25 stycznia podkreślił, że Kościół od początku dawał narodowi „stałość swej nauki ewangelicznej, bo głosił Ewangelię wszelkiemu stworzeniu - zarówno kmieciom, jak i możnowładcom. Chociaż ich stosunek do zasad moralności chrześcijańskiej - niełatwej przecież i dla nas dzisiaj - był różny, jednakże Kościół miał te same wartości duchowe, intelektualne, moralne i społeczne dla wszystkich warstw ówczesnej ojczyzny. [...] Oczekujemy od państwa, aby umiejętnie koordynowało prawa i obowiązki wszystkich warstw społecznych - czy to będą rolnicy, czy pracownicy rolni, robotnicy przemysłowi, technicy, czy inteligencja. [...] Czego jeszcze Kościół oczekuje od państwa? Aby stało na straży praw obywateli, rodziny, narodu, państwa. [...] Aby państwo nie narzucało obywatelom jakiejś ideologii państwowej. Nie chodzi tylko o monizm filozoficzny, ale i o materializm dialektyczny"19. Był to jasny program dla polskiego Episkopatu w sytuacji, gdy w państwie obowiązywał monopol PZPR, wszechobecny podział na partyjnych i bezpartyjnych. Prymas miał tego pełną świadomość, w lutym 1974 r. stwierdził: „postawa religijna dyskwalifikuje człowieka partyjnie i obywatelsko, wtedy gdy członek partii, nawet o słabych kwalifikacjach obywatelskich i zawodowych, jest eksponowany. Jest to państwo, które dys-

17 AAG, S, Wyszyński, Pro memoria 1975, zapis z 17 II 1975. Troskę o związek Kościoła z narodem prymas wyrażał wielokrotnie także w czasie posiedzeń Rady Głównej Episkopatu przykładowo w czasie obrad z 16 sierpnia 1974 prymas wskazywał, że „Episkopat musi wczuwać się w opinię publiczną polskiego środowiska” AAW, SPP 04/29, Rada Główna Episkopatu Polski 1974, k. 115 protokół RG EP z 16 VIII 1974.

18 P. Raina, Stefan Kardynał Wyszyński. Prymas Tysiaclecia, t. 4, Warszawa 2016, s. 455-462. O tym cyklu zob. szerzej Konferencje Księdza Prymasa w kościele Świętego Krzyża, „Wiadomości Archidiecezjalne Warszawskie” 1974, s. 111-112; Świętokrzyskie kazania Księdza Prymasa, „Wiadomości Archidiecezjalne Warszawskie 1976, s. 55; E. Czaczkowska, Kardynał Wyszyński..., s. 654-663. Pełna treść kazań zob. S. Wyszyński, Nauczanie społeczne 1946-1981, Warszawa 1990, s. 174 i n. Komuniści mieli świadomość znaczenia cyklu, z tego też względu na przełomie 1976/1977 wypuścili fałszywe wydanie kazań z 1974 r. Prymas zareagował polecając wydanie specjalnego komunikatu: Ostrzeżenie Sekretariatu Prymasa Polski w sprawie sfałszowanego tekstu „Kazań Świętokrzyskich”, II 1977, Warszawa, „Wiadomości Archidiecezjalne Warszawskie” 1977, s. 123-124.

19 P. Raina, Stefan Kardynał Wyszyński. Prymas Tysiąclecia..., t. 4, s. 459-462. 
kwalifikuje znaczną część obywateli z racji ich przynależności religijnej i wyznaniowej, z racji ich przekonań religijnych, co jest przeciwne postanowieniom konstytucji"20.

W czasie rozmowy z papieżem Pawłem VI z 15 grudnia 1975 r. kard. Wyszyński dodał interesującą myśl, która można traktować jako spostrzeżenie wnikliwego obserwatora systemu komunistycznego w praktycznym działaniu: „U nas np. i wszędzie, gdzie komunizm rządzi, choćby silną ręką «lekarstwo groźniejsze od choroby» - jednak wyleczyło z komunizmu społeczeństwo. Wyleczyli się robotnicy, inteligencja /może w mniejszym stopniu/ i ludność rolnicza. Tylko tam, gdzie komunizm nie rządzi jest on chorobą. Tam, gdzie rządzi staje się tak dokuczliwy, że odstręcza ludzi od siebie"21. Równie interesująca była refleksja z 10 sierpnia 1977 r. (ze spotkania z kard. Terencem Jamesem Cookiem), w której prymas w generalny sposób oceniał kondycje ideologii komunistycznej w PRL: „Usiłuję wytłumaczyć, że 1. marksizm, zawodzi doktrynalnie, chociaż na Zachodzie jeszcze ludzi interesuje; 2. zawodzi społecznie, niechęć wśród robotników; 3. zawodzi kulturalnie, gdyż przez ateizację ludzi zastrzeżenia Narodu, wychowanego na kulturze

${ }^{20}$ AAW, SPP, 04/29, Rada Główna Episkopatu Polski 1974, k. 40, Protokół Rady Głównej Episkopatu Polski, 21 II 1974. Na temat walki władz partyjno-państwowych z tzw. religianctwem zob. szerzej K. Kosiński, „Religianctwo”. Napięcie między ideologiq a religiq w świadomości członków i działaczy PZPR, „Polska 1944/45-1989. Studia i materiały" 2014 (12), s. 107-204.

${ }^{21}$ AAG, S, Wyszyński, Pro memoria 1975, zapis z 15 XII 1975. Prymas uzupełnił swoją refleksję dwa dni później zanotował: „Ten totalizm jest przekreśleniem narodu, społeczeństwa, państwa. Jest to «totalizm partyjny», a więc stosunkowo wąskiej kliki dobranych ludzi, poprzetykanych obcym narodowo elementem. To sprowadza apatię narodu i Partia zostaje osamotniona. W narodzie budzi się zakamuflowany opór, którego Partia nie może przezwyciężyć. Komunizm idzie naprzód militarnie /Portugalia, Angola, Liban/, wywołując lokalne awantury, by odwrócić uwagę państw, zdolnych do interwencji. Ale komunizm cofa się społecznie, tzn. traci bazę społeczną, narodową, a nawet zawodową.- Potęgi militarne bez podparcia społeczeństwa i narodu są skazane na upadek, wpierw czy później /Hitleryzm/.I dlatego choroba w tym wypadku jest też i lekiem. W Polsce wyleczeni są niemal wszyscy, robotnicy, inteligencja, młodzież, rolnicy. Pozostaje tylko aparat partyjny, najemników uprzywilejowanych ekonomicznie. Bo nawet oni «są niewierzącymi w marksizm». Widzimy to w stylu obrad VII Zjazdu Partii. - Tej «galówki» nikt nie słucha, nie czyta. Partia to wie, że granice propagandy stoją na punkcie martwym", ibidem, zapis z 17 XII 1975. 
łacińskiej; 4. zawodzi też ekonomicznie, co łatwo dostrzec. Dziś jako jedyna broń - pozostaje odwieczny militaryzm Rosyjski, na użytek ustroju"22.

Kardynał Wyszyński w latach 1974-1978 wielokrotnie wracał do problemu braku wolności religijnej i upośledzenia katolików w rzeczywistości społeczno-politycznej PRL ${ }^{23}$. Jasno wskazywał to w swoim dzienniku Pro memoria. Przykładowo, w notatce z 15 stycznia 1975 r. podkreślał, odnosząc się do sytuacji w całym bloku wschodnim: „Alienacja osobowości prowadzi do alienacji Narodu. Zjawisko to powtarza się wszędzie, grozi i Polsce. - Trzeba stać na straży podstawowych praw osoby ludzkiej - to obowiązek Kościoła i Jego ludzi" ${ }^{24}$. Analogiczne stanowisko zajął w czasie obrad Rady Głównej Episkopatu z 21 lutego 1974 r., gdy odnosząc się do złudzeń dyplomatów watykańskich przyjeżdzających do PRL zaznaczał: „Trudno im wyobrazić sobie instytucją państwową, opartą na monopolu partyjnym, ze wszystkimi konsekwencjami dla państwa, które jest podzielone na partyjnych i bezpartyjnych, gdzie postawa religijna dyskwalifikuję człowieka partyjnie i obywatelsko wtedy, gdy członek partii nawet o słabych kwalifikacjach obywatelskich i zawodowych, jest eksponowany. Jest to państwo, które dyskwalifikuję znacząca część obywateli z racji ich przynależności religijnej i wyznaniowej, z racji ich przekonań religijnych, co jest przeciwne postanowieniom Konstytucji”25. Zaznaczał, że działania władz są wbrew prawom człowieka: „polityczna ateizacja nie stanowi procesu racjonalistycznego, ale jest znie-

22 AAG, S, Wyszyński, Pro memoria 1977, zapis z 10 VIII 1977.

23 AAG, S, Wyszyński, Pro memoria 1975, zapis z 14 I 1975; AAG, S. Wyszyński, Pro memoria 1976, zapis z 22 IV 1976; ibidem, zapis z 6-10 VII 1976; AAW, SPP 04/29, Rada Główna Episkopatu Polski 1974, k. 132, Protokół KGEP z 25 XI 1974; AAW, SPP 04/31, Rada Główna Episkopatu Polski 1976, k. 54-56, protokół KG EP z 11 VI 1976; AIPSKW, S. Wyszyński, Kazania i przemówienia autoryzowane, t. LVIII, „Portes in Fide”. Uroczystość pięciolecia erygowania diecezji koszalińsko-kołobrzeskiej, 26 VI 1977, Słupsk, s. 77-79. Wspomniane wątki pojawiły się także w memoriałach Episkopatu skierowanych do rządu PRL w sprawie nowelizacji konstytucji (temat ten zostanie omówiony w osobnych rozważaniach poniżej). Prymas traktował upominanie władz Polski „ludowej” w tym zakresie jako swój obowiązek, S. Wyszyński, Trzy wieżyce nad Polską..., s. 64.

24 AAG, S, Wyszyński, Pro memoria 1975, zapis z 15 I 1975.

25 AAW, SPP 04/29, Rada Główna Episkopatu Polski 1975, k. 40, Protokół KGEP z 21 II 1974, Warszawa. Analogiczne uwagi zgłosił rok później: AAW, SPP 04/30, Rada Główna Episkopatu Polski 1975, k. 6, Protokół KGEP z 14 I 1975. 
woleniem godzącym w godność człowieka"26. Tego typu wątki pojawiały się również wielokrotnie w Homiliach wygłaszanych przez prymasa w tym okresie czasu $^{27}$. Prymas podkreślał to przykładowo w czasie wystąpienia wygłoszonego w Zbroszy Dużej ${ }^{28}$ : „Zapamiętajcie to, co wam w tej chwili mówię: ani ja, ani Biskupi, ani Kościół w Polsce, ani katolicy polscy, nie prowadzimy walki z Rządem, partią, ustrojem czy urządzeniami, które są obecnie zaprowadzane; my tylko prowadzimy serdeczny spór o Boga dla naszej Ojczyzny [podkreślenie w oryginale - RŁ], Narodu i Państwa, w jakimkolwiek by ono żyło ustroju. Prowadzimy walkę o Boga dla rodzin polskich, które są przeważnie katolickie, dla młodzieży i dzieci. Jest to jedyny [jw.- RŁ] spór, walka i bój jaki toczymy. Nie jest to jednak bój z ludźmi, ale spór o prawa, jakie ma wierzący Naród, w swej wolnej Ojczyźnie, wywalczonej przecież społem i społem rozbudowywanej, głównie przez katolików, którzy stanowią ponad $95 \%$ obywateli naszego kraju"29.

Prymas w swoich homiliach z tego okresu czasu wskazywał także na rangę problemów demograficznych w polskim społeczeństwie. Jasno i otwarcie przeciwstawiał się ustawie o przerywaniu ciąży; podkreślał, że zwiększenie

${ }^{26}$ AAW, SPP 04/30, Rada Główna Episkopatu Polski 1975, k. 8, Protokół KGEP z 14 I 1975.

${ }^{27}$ AIPSKW, S. Wyszyński, Kazania i przemówienia autoryzowane, t. XLVII, „Polska ale jaka?”. Do młodzieży polskiej z Anglii, 4 VIII 1974, Warszawa, s. 31; idem, O chrześcijańskq wizję życia. Do wiernych $w$ Warszawie, 10 II 1974, Warszawa [w:] idem, Nauczanie społeczne..., s. 597-603; idem, Apel synodu w obronie praw człowieka. Po powrocie z synodu biskupów, 26 I 1975, Warszawa [w:] ibidem, s. 625-626; Program walki o życie narodu. Podczas wizytacji parafii Świętego Mikołaja w Warszawie, 16 III 1975 [w:] ibidem, s. 641; idem, Czego pragniemy dla stolicy i narodu. Podczas procesji Bożego Ciała w Warszawie, 17 VI 1976, Warszawa, [w:] ibidem, s. 738-742;

${ }^{28}$ Walka wiernych o świątynie w Zbroszy Dużej trwała kilkanaście lat i zakończyła się ostatecznie sukcesem w 1974 r. Zob. szerzej, G. Łeszczyński, Początki parafii w Zbroszy Dużej, Warszawa 2007.

${ }^{29}$ AIPSKW, S. Wyszyński, Kazania i przemówienia autoryzowane, t. XLVII, „Smutek wasz w radość się obrócił”. Poświęcenie kościoła w Zbroszy Dużej, 17 VIII 1974, s. 32. Analogiczne słowa prymas wygłosił cztery lata później na krakowskiej Skałce, gdzie równie silnie zaznaczył, że Kościół nie walczy z ludźmi władzy, tylko z ich błędami oraz niesprawiedliwościami, których się dopuszczają, AIPSKW, S. Wyszyński, Kazania i przemówienia autoryzowane, t. LX, „Trwały wzór życia dla Polaków”. Uroczystość Świętego Stanisława, 7 V 1978, Szczepanów, s. 28. 
ilości urodzin jest sprawa narodowego „być albo nie być”30. Podobnie było jeśli chodzi o wychowanie seksualne, które w jego przekonaniu nie mogło polegać „na propagandzie rozwodów, środków antykoncepcyjnych, uprawnień do przerywania ciąży, na nauce o chorobach wenerycznych, o sposobach wystrzegania się konsekwencji współżycia dwojga. To jest wywrócenie porządku"31. Kardynał Wyszyński zdecydowanie wskazywał na konieczność pracy katolików nad sobą w zakresie pogłębienia moralności, przykładowo w czasie homilii wygłoszonej w Gnieźnie 25 kwietnia 1976 r. zaznaczał: „Dzieci Boże. Czuwajmy też nad poprawą naszych obyczajów w życiu osobistym, w rodzinie, w środowisku pracy, na ulicy, aby wiadomo było, że jesteśmy narodem chrześcijańskim nie tylko $\mathrm{z}$ imienia, ale przede wszystkim z czynów, z codziennego życia! Pamiętajmy, że Ewangelia Chrystusowa wniosła do rodzin polskich nowy, z trudem wypracowany obyczaj - wierność małżeńską i poszanowanie życia nienarodzonych. Bądźmy świadomi, że młoda Polska rodzi się nie gdzie indziej, tylko pod sercem matki, w rodzinie domowej. Trzeba tę kolebkę narodu uszanować! Trzeba czuwać nad tym, aby nie uczynić niczego, co szkodziłoby przyrostowy naturalnemu narodu"32.

Ważnym dla prymasa (i całego polskiego Kościoła) polem działania w latach 1974-1978 była troska o młodzież i jej wychowanie. Kardynał Wyszyń-

30 S. Wyszyński, W obronie życia Polaków. Do wiernych w Warszawie, 9 III 1975, Warszawa [w:] idem, Nauczanie społeczne..., s. 632. Analogiczne wskazania prymas zawarł w homilii wygłoszonej na krakowskiej Skałce 12 maja 1974 r. (M. P. Romaniuk, Życie, twórczość... t. IV, s. 172-173); czy tez w: Słowo Pasterskie na prace wielkopostne i radości wielkanocne. Do duchowieństwa i wiernych Archidiecezji Gnieźnieńskiej i Warszawskiej, 2 II 1977, Gniezno-Warszawa [w:] Listy pasterskie Prymasa..., s. 64-65.

31 S. Wyszyński, Program walki o życie narodu..., s. 637. Zob. także, AIPSKW, S. Wyszyński, Kazania i przemówienia autoryzowane, t. XLV, „Do pracowników duszpasterstwa rodzin", 3 II 1974, Gniezno, s. 86-90; Ratujmy życie w rodzinie. List pasterski na XXXIV Tydzień Miłosierdzia, 26 VII 1978, Warszawa, [w:] ibidem, s. 839-844.

32 Cyt. za: M. P. Romaniuk, Życie, twórczość... t. IV, s. 323. Analogiczne wskazana zawarł w liście pasterskim z 2 marca 1975 r. skierowanym do wiernych archidiecezji gnieźnieńskiej, S. Wyszyński, Zachęta do przygotowania serc na Święta Paschalne, 2 III 1975, Gniezno [w:] Listy pasterskie Prymasa Polski oraz Episkopatu 1975-1981, Paris 1988, s. 25. Z kolei w homilii wygłoszonej w kwietniu 1976 r. w Gnieźnie wskazywał na słabość moralną w życiu codziennym katolików, m.in. na nadużywanie alkoholu, AIPSKW, S. Wyszyński, Kazania i przemówienia autoryzowane, t. LIII, „W obronie wiary narodu”. Przemówienie podczas sumy w uroczystość św. Wojciecha, 25 IV 1976, Gniezno, s. 265-266. 
ski jasno wskazywał: „Jest rzeczą wielkiej wagi, aby młodzież akademicką włączać w aktualne życie i sprawy Kościoła"33. Działania Episkopatu w tej sferze odbywały się na trzech płaszczyznach: aktywizacji i zmiany funkcjonowania duszpasterstw akademickich, przypominania rodzicom, by wychowywali młode pokolenie, bazując na wartościach chrześcijańskich, i oporu przeciwko inicjatywom struktur partyjno-państwowych ${ }^{34}$. Starania biskupów były energiczne, znacząco zintensyfikowano aktywność duszpasterstw akademickich Episkopat kierował do władz i społeczeństwa szereg listów i memoriałów w tej sprawie. Głównym ich inicjatorem obok kard. Wojtyły był prymas Wyszyński ${ }^{35}$.

Kardynał Wyszyński wielokrotnie osobiście przemawiał do młodzieży nakreślając jak Kościół widzi ich społeczną rolę; mówił również o wymaganiach jakim powinna ona sprostać; nakreślał także zadania dla duszpasterzy tej grupy społecznej ${ }^{36}$. W czasie homilii z 9 kwietnia 1974 r podczas zakończenia rekolekcji do studentów prymas podkreślał: „Nadszedł czas abyście umieli powiedzieć waszym wychowawcom i profesorom na uczelniach: Uczcie nas prawdy, a nie rujnujcie nas, nie odbierajcie nam wiary! Nie niszczcie naszego chrześcijańskiego stylu moralnego przez głupawy laicyzm, którego sensu właściwie nikt nie pojmuje, a na propagandę którego wydaję się tyle pieniędzy. [...] Nadszedł czas, abyście nawet nam, kapłanom i biskupom odważnie

${ }^{33}$ S. Wyszyński, Trzeba wprowadzać młodzież w problemy Kościoła w Polsce. Do duszpasterzy akademickich $w$ Niepokalanowie, 9 XII 1976, Niepokalanów [w:] idem, Nauczanie społeczne..., s. 761.

${ }^{34}$ Ze szczególny oporem prymasa i Episkopatu spotkała się koncepcja wprowadzenia reformy wychowania zaprojektowanej przez Ministerstwo Oświaty, AIPSKW, S. Wyszyński, Kazania i przemówienia autoryzowane, t. LI, „Zaplecze normalizacji”. Podczas konferencji diecezjalnych referentów duszpasterstwa, 22 IX 1975, s. 237-239.

${ }_{35}$ Zob. szerzej R. Łatka, Episkopat Polski..., s. 156-180. Jan Żaryn trafnie zauważył, że lata siedemdziesiąte stały pod znakiem ekspansji duszpasterskiej Kościoła, mającej zapobiec atomizacji i ateizacji społeczeństwa, idem, Stosunki państwo-Kościót katolicki w latach siedemdziesiatych XX w. [w:] „Oaza wolności”. Duszpasterstwa akademickie w latach siedemdziesiattych XX w., red. M. Marcinkiewicz, Szczecin 2011, s. 16

${ }^{36}$ AIPSKW, S. Wyszyński, Kazania i przemówienia autoryzowane, t. XLV, „Przemówienie do diecezjalnych duszpasterzy młodzieżowych", 18 IV 1974, Warszawa, s. 228-236; AIPSKW, S. Wyszyński, Kazania i przemówienia autoryzowane, t. LV, „Należy wprowadzać młodzież w problemy Kościoła w Polsce”. Do duszpasterzy akademickich, 9 XII 1976, Niepokalanów, s. 137-139. 
powiedzieli: nie podoba się nam wasz wyrozumiały styl, zmiękczający nasze życie. Nie podoba się nam, że już nie macie odwagi stawiać nam wymagań. Jeśli widzicie w nas wady, poprawiajcie je, bo jesteście od tego. Nie chcemy takich duszpasterzy, którzy nie mają odwagi stawiać nam wymagań" ${ }^{37}$. Prymas osobiście protestował też przeciwko młodzieżowym, wiosennym „czynom społecznym”, które miały się odbywać w niedziele. W piśmie protestacyjnym skierowanym do ministra oświaty i wychowania Jerzego Kuberskiego wskazywał, że zakłócają one religijne obowiązki i dezorganizują odpoczynek młodzieży. Zaznaczał, iż „Takie iście faraońskie formy wyzysku są niezgodne z obowiązującymi przepisami o odpoczynku od pracy. Budzą opór i napięcie społeczne wśród młodzieży, doprowadzając niekiedy do stanu wrzenia, które może mieć nieobliczalne następstwa" ${ }^{38}$.

Mimo braku przekonania o skuteczności regularnie wysyłanych przez Episkopat do władz memoriałów w latach $1970-1974^{39}$ postulował w styczniu 1975 r. podtrzymywanie tego typu działań: „Na płaszczyźnie prawnej występowaliśmy z szeregiem memoriałów na różne tematy do władz państwowych. Memoriały te nie zawsze mają rezonans. Władze albo nie odpowiadają na nie, albo odpowiadają zdawkowo. Tę płaszczyznę należy podtrzymać na przyszłość. Na płaszczyźnie społecznej należy się zwracać wprost do ludzi, podejmować tematy, które sformułował synod Biskupów w swoich dokumentach. [...]"40. 14 kwietnia 1975 Episkopat wystosował do rządu PRL memoriał w sprawie dyskryminacji katolików w życiu publicznym, który jako od-

37 AIPSKW, S. Wyszyński, Kazania i przemówienia autoryzowane, t. XLV, „Kościół stawia wam wymagania”. Zakończenie rekolekcji do młodzieży akademickiej, 9 IV 1974, Warszawa, s. 216-217.

38 M. P. Romaniuk, Życie, twórczość... t. IV, s. 159-160. Analogiczne słowa prymas wypowiedział publicznie w Krakowie w czasie homilii na Skałce, AIPSKW, S. Wyszyński, Kazania i przemówienia autoryzowane, t. XLVI, „Prosimy, wymagamy, żądamy”. Podczas uroczystości św. Stanisława Męczennika, 12 V 1974, Kraków, s. 64-65.

${ }^{39} \mathrm{Na}$ ten temat zob. szerzej, R. Łatka, Episkopat Polski...s. 259-275.

40 AAW, SPP, 04/275, k. 52, Protokół KPE, 15-16 I 1975; AAG, S, Wyszyński, Pro memoria 1975, zapis z 14 I 1975. Analogicznie kard. Wyszyński pisał w swoim dzienniku 17 września 1975 r. Odnosząc się do przebiegu swojej rozmowy ze Stanisławem Stommą prymas podkreślał, że „Kościół nie zamknął się do swoich spraw, ale przez Memoriały kierowane do Władz stawał w obronie Narodu i jego kultury", AAG, S, Wyszyński, Pro memoria 1975, zapis z 11 IX 1975. Prymas zajął w tej sprawie stanowisko również w publiczny sposób w czasie homilii wygłoszonej w Krakowie, S. Wyszyński, Prosimy - wy- 
notowali biskupi wywołał w elitach władzy partyjnej oburzenie ${ }^{41}$. Znalazł się w nim bowiem wykaz wszystkich interwencji polskich biskupów wobec ekipy Gierka ${ }^{42}$ i wiele zdecydowanych sformułowań dowodzących społecznego upośledzenia katolików i ludzi wierzących ${ }^{43}$.

Biskupi zgodnie ze wskazaniem prymasa nie zaprzestali przesyłać memoriałów do władz również w kolejnych latach ${ }^{44}$. Przykładowo 8 listopada 1976 r. biskupi przedstawili List w obronie wiary, w którym domagali się poszanowania praw religijnych społeczeństwa ${ }^{45}$. Wskazali m.in., że wiara ma doniosłe znaczenie dla życia rodzinnego, a „żadne ludzkie prawa, przepisy i sankcje nie są w stanie tak zabezpieczyć całości, zwartości i owocności rodziny, jak żywa, jednocząca wiara ich członków"46. Podkreślili, iż mimo deklaracji o normalizacji w Polsce władze nadal toczą walkę z religią, ograniczają wolność sumienia i wyznania oraz dyskryminują wierzących. Opisali szykany w zakresie budownictwa sakralnego i dostępu do wysokich stanowisk pracy dla osób niekryjących się z wiarą. Zwrócili uwagę, że jest realizowana programowa ateizacja, a środki masowego przekazu upowszechniają antychrześcijańskie zasady moralne ${ }^{47}$.

Podejście prymasa (i Episkopatu) okazało się słuszne, gdyż memoriały dot. nowelizacji konstytucji PRL przyniosły konkretny efekt, co zostanie omówione w dalszej części tekstu.

magamy - żadamy. Podczas uroczystości świętego Stanisława w Krakowie, 12 V 1974 [w:] idem, Nauczanie społeczne..., s. 615.

41 AAW, SPP 04/30, Rada Główna Episkopatu Polski 1975, k. 49, Protokół KGEP z 3 V 1975.

42 AAG, S. Wyszyński, Pro memoria 1975, zapis z 25 IV 1975 r.

43 P. Raina, Kardynał Wyszyński. Czasy prymasowskie 1975, Warszawa 2006, s. 50-57.

${ }_{44}$ Pełne ich omówienie zob. R. Łatka, Episkopat Polski...s. 278-296.

${ }^{45}$ Wezwanie do modlitwy w obronie wiary świętej w Ojczyźnie, 8 XI 1976, Warszawa [w:] Listy pasterskie Episkopatu Polski 1945-2000, część I, red. P. Libera, A. Rybicki, S. Eącki, Marki 2003, s. 1076-1081.

46 Ibidem, s. 1077.

47 Ibidem, s. 1077-1079. 


\section{Relacje państwo-Kościół}

S. Wyszyński, posiedzenie KEP z 26-27 VI 1975:

Nasza linię postępowania można zamkną́ w stowach: „bronić się przed ingerencja władz państwowych $w$ wewnętrzne sprawy Kościoła" ${ }^{\prime \prime}$.

W zakresie relacji państwo-Kościół w latach 1974-1978 nie doszło do żadnego poważniejszego przełomu. Postulaty prymasa i biskupów takie jak: ustanowienie osobowości prawnej Kościoła, rezygnacja z polityki programowej laicyzacji społeczeństwa, zgoda władz na zwiększenie budownictwa sakralnego, likwidacja służby wojskowej alumnów, czy reaktywacja Komisji Wspólnej rządu PRL i Episkopatu Polski, mimo ich nieustannego podnoszenia, nie znajdowały większego zrozumienia w elitach władzy Polski „ludowej”. Analogicznie było w przypadku domagania się szerszego marginesu dla społecznej działalności Kościoła, na co wielokrotnie w swoich homiliach i wystąpieniach publicznych wskazywał kard. Wyszyński ${ }^{49}$. Edward Gierek wyrażał zgodę tylko na drobne korekty w polityce wyznaniowej polegające na wydaniu nieco większej liczby pozwoleń na budowę kościołów oraz zmniejszenie liczby kleryków powoływanych do wojska. Tego typu zmiana nie wynikała jednakże z dobrej woli I sekretarza KC PZPR, ale przede wszystkim z realizacji polityki różnicowania biskupów ${ }^{50}$.

Kardynał Wyszyński w 1974 r. sytuację w tym zakresie oceniał pesymistycznie: „Niektórzy księża już uważają, że jesteśmy bliscy normalizacji. Właśnie jest teraz czas odpowiedni, by poszerzać problematykę, która leży na linii Kościól-państwo. Nie idzie o to, żebyśmy czegoś się spodziewali od państwa - państwo już się wygadało i chciałoby, żebyśmy jak konie w kieracie chodzili pod dyktando partii. Od strony materialnej zyskaliśmy coś na normalizacji

48 AAW, SPP 04/277, k. 31, Protokół KPE, 26-27 VI 1975.

49 AIPSKW, S. Wyszyński, Kazania i przemówienia autoryzowane, t. XLV, „Do pracowników duszpasterstwa rodzin", 3 II 1974, Gniezno, s. 92-93.

50 O polityce różnicowania biskupów zob. szerzej, K. Pawlicka, Polityka władz wobec Kościoła..., s. 95-122; R. Łatka, Relacje państwo-Kościót w pierwszych latach rządów Edwarda Gierka - czyli jak wyglądała polityka „normalizacji” w praktyce, [w:] Państwo-religia. Instytucje państwowe i obywatele wobec religii w Europie Środkowo-Wschodniej w XX w., tom II, red. J. Durka, Kalisz 2018, s. 221-226. 
Z[iem] Z[achodnich] i Półn[ocnych], ale na odcinku wewnątrzkościelnym, religijnym i duchowym co? Musimy utrzeźwiać ludzi i zwracać uwagę na to wszystko, co nie zostało dotąd załatwione. Należałoby przypomnieć władzom państwowym nasze memoriały o zagrożeniu biologicznym, o wolności religijnej i żądać na nie odpowiedzi. Musimy wspierać inicjatywy katolików świeckich, którzy zaczynają się budzić i domagać swoich praw" ${ }^{51}$. Prymas w czasie rozmowy z posłem Konstantym Łubieńskim, która miała miejsce 24 stycznia 1975 r. podkreślał dość zdecydowanie, że Kościół spotyka ze strony władz wiele dokuczliwości ${ }^{52}$. Z kolei w czasie spotkania z abp. Poggim z 24 marca zaznaczał, że rząd PRL odsuwa na bok wszelkie „sprawy i potrzeby” Kościoła w Polsce ${ }^{53}$.

Prymas w odpowiedzi na pytania i kwestie podniesione przez biskupów w czasie obrad plenarnych z 20 czerwca 1974 r. podkreślił, że powinni oni informować duchowieństwo o stosunkach państwo-Kościół oraz nakreślił wytyczne do działania

„1/ Biskupi powinni w listach pasterskich naświetlać napotkane w terenie trudności. Dotyczy to także święcenia niedzieli.

2/ Trudności administracyjne w terenie nalży badać, interweniować na miejscu i notyfikować je w Sekretariacie Episkopatu.

3/ Kapłani oddani posłudze Ludowi Bożemu nie powinni przyjmować żadnych odznaczeń nie mających charakteru religijnego [...]"54.

Biskupi w czasie obrad Episkopatu ze stycznia 1975 r. ustalili sposób w jaki powinni działać wobec polityki wyznaniowej władz: „Konieczna jest zwartość narodu, hierarchii i duchowieństwa, a przede wszystkim czynna troska dusz-

${ }^{51}$ AAW, SPP, 04/29, Rada Główna Episkopatu Polski 1974, k. 21, protokół RG EP z 22 I 1974 r. Analogiczne wskazania prymas przekazał wszystkim biskupom w czasie styczniowego posiedzenia plenarnego Episkopatu gdzie podkreślał, że trzeba stawiać i przypominać problemy zasadnicze. [...] Księża Biskupi powinni uwrażliwiać swoich księży i wiernych, na to co stanowi istotna treść normalizacji, by nie sprowadzać jej do zagadnień ekonomicznych", AAW, SPP 04/269, k. 60-61, protokół KPE, 23-24 I 1974, Warszawa. Podobnie sytuację oceniał rok później, AIPSKW, S. Wyszyński, Kazania i przemówienia autoryzowane, t. LI, „Zaplecze normalizacji”. Podczas konferencji diecezjalnych referentów duszpasterstwa, 22 IX 1975, s. 233-243.

${ }^{52}$ AAG, S, Wyszyński, Pro memoria 1975, zapis z 24 I 1975.

${ }^{53}$ Ibidem, zapis z 24 III 1975.

${ }^{54}$ AAW, SPP 04/272, k. 27, Protokół KPE, 19-20 VI 1974. 
pasterska i nieprzerwany kontakt z wiernymi. Musimy wszystko zrobić, żeby nie dopuści do alienacji wewnętrznej Polaków oraz w ramach możliwości bronić naszych braci sąsiadów od alienacji" 55 .

Rzeczywiste podejście komunistów do postulatów kościelnych i ich obłudę w pełni pokazał referat K. Kąkola kierownika UdsW dla dziennikarzy PAP i działaczy partyjnych z 5 maja 1976 r., w którym znalazły się m.in. słowa: „Wstydzę się, kiedy komuniści z innych krajów pytają mnie, dlaczego wciąż tylu Polaków chodzi do kościoła. Wstydzę się, gdy goście zagraniczni winszują mi rozwoju religii w naszym kraju. [...] Wykorzenienie religii ze świadomości i myśli ludzkiej jest procesem skomplikowanym i długotrwałym. Nie dokonamy tego za jednym zamachem. Musimy unikać atakowania agresywną przemocą, gdyż wtedy Kościół okaże się obsadzoną twierdzą, co spowoduje zwiększenie jego popularności"56. Wystąpienie Kąkola opublikował w sierpniu 1977 r. francuski periodyk „Documentacion”, dzięki czemu dość szybko zyskało ono rozgłos i dotarło do Watykanu ${ }^{57}$. Na sesji Rady Głównej we wrześniu 1976 r. biskupi podkreślali, że wypowiedź kierownika UdsW obnażyła komunistów oraz ich cele wobec Kościoła. Prymas stwierdził jednakże, że to wydarzenia ma również pewne korzystne aspekty: „w fakcie ujawnienia polityki rządu PRL wobec Kościoła są pewne korzyści ad intra i ad extra. Szczególnie w Watykanie pozwoliły zrozumieć nasze zastrzeżenia odnośnie [do] Ostpolitik. Dotychczas nasze naświetlenia były przyjmowane z rezerwą"58.

Prymas wspomniane wystąpienie omówił także 20 sierpnia 1976 r. w czasie kursu przygotowawczego do roku katechetycznego dla warszawskiego duchowieństwa. Podkreślał, iż referat K. Kąkola wskazywał na nasilenie ideologicznego zwalczania Kościoła w Polsce, które w jego przekonaniu ma wymiar bardziej polityczny niż doktrynalny. W związku z tym zaznaczał, że kapłani powinni być nauczycielami-wyznawcami prawdy ewangelicznej oraz

55 AAW, SPP 04/275, k. 51, Protokół KPE, 15-16 I 1975.

56 Cyt. za P. Raina, Kardynał Wyszyński. Czasy prymasowskie 1976..., s. 137.

57 Komunistyczny wywiad uznał, ze fragmenty wypowiedzi min. Kąkola przekazał francuskiemu pismu bp Dąbrowski, ale nie zostało to potwierdzone, AIPN, 02011/535, Departament I MSW, k. 10, Informacja dotycząca kolportażu na Zachodzie fragmentów majowego wystąpienia min. Kąkola, 3 II 1977 r., Paryż.

58 AAW, SPP, 04/31, Rada Główna Episkopatu Polski 1976, k. 68, Protokół RG EP, 7 IX 1976. Por. AAW, SPP, 04/283, k. 82-83, Protokół KPE, 8-9 IX 1976; AAG, S. Wyszyński, Pro memoria 1976, zapis z 7 IX 1976. 
unikać złudzeń co do charakteru działań władz wobec Kościoła ${ }^{59}$. Co zaskakujące kard. Wyszyński mówił: „Niewątpliwie pracujemy w bardzo trudnych warunkach; niewątpliwie spotkamy się w Polsce z zorganizowaną propagandą ateistyczną; niewątpliwie walka ideologiczna jest prowadzona, ale ta walka jest nie tylko wrogiem, ale jest niekiedy i sprzymierzeńcem. Gdyby była prowadzona w bardzo pomyślnych dla społeczeństwa warunkach, mogłaby być większym wrogiem. Ale ponieważ jest prowadzona w bardzo trudnych warunkach i społeczeństwo znajduję nie tylko teologiczne racje obrony, ale także ekonomiczne, dlatego ta walka staję się często naszym sprzymierzeńcem"60.

Ważną dla kard. Wyszyńskiego kwestią w zakresie relacji z państwem była nominacja następcy kard. Bolesława Kominka na stolicy arcybiskupiej we Wrocławiu. Pokazywała ona jak w soczewce, że „normalizacja” stosunków ma jedynie propagandowy charakter. Batalia $\mathrm{z}$ władzami dot. tej sprawy trwała dwa lata ${ }^{61}$ i zakończyła się połowicznym zwycięstwem prymasa. Metropolita wrocławskim został jego kandydat bp. Henryk Gulbinowicz ówczesny administrator apostolski w Białymstoku, ale przywódca polskiego Kościoła nie widział o jego tajnych rozmowach prowadzonych z funkcjonariuszami MSW od $1969 \mathrm{r}^{62}$; choć równocześnie miał świadomość, że wśród polskich biskupów nie brakowało lepszych kandydatów na to stanowisko ${ }^{63}$.

Prymas nie przejmował się również oskarżeniami wysuwanymi przez władze pod adresem części biskupów, że prowadzą oni „działalność antypaństwową"64. Wręcz przeciwnie uważał, że tego typu zarzuty świadczą o tym, iż

59 AAG, S. Wyszyński, Pro memoria 1976, zapis z 20 VIII 1976; AIPSKW, S. Wyszyński, Kazania i przemówienia autoryzowane, t. LIV, „Do kapłanów katechetów na zakończenie roku kursu katechetycznego", 20 VIII 1976, Warszawa, s. 238-239.

60 Cyt. za M. P. Romaniuk, Życie, twórczość... t. IV, s. 355.

61 Prymas podkreślał, że walka toczyła się nie tyle o samo obsadzenie wrocławskiej stolicy arcybiskupiej, ale wolność Kościoła w ustanawianiu biskupów, AIPSKW, S. Wyszyński, Kazania i przemówienia autoryzowane, t. LI, „W odpowiedzi na życzenia imieninowe duchowieństwa”, 2 VII 1975, Warszawa, s. 22.

62 R. Eatka, Episkopat Polski..., s. 464-474. Na temat walki prymasa o nominacje następcy kard. Kominka zob. szerzej, P. Raina, Sprawa obsadzenia metropolii wrocławskiej 1974-1976. Eskapady władz PRL, Pelplin 2006.

63 AAG, S. Wyszyński, Pro memoria 1975, zapis z 15 XII 1975.

${ }^{64} \mathrm{~W}$ drugiej połowie lat siedemdziesiątych dot. to przede wszystkim kard. Karola Wojtyły i bp. Ignacego Tokarczuka. Na temat inwigilacji oraz działań bezpieki wymierzonych w tych dwóch hierarchów zob. szerzej, P. Chmielowiec, M. Krzysztofiński, Abp Igna- 
pomawiani przez rząd PRL hierarchowie dobrze pracują. Kardynał Wyszyński jasno to podkreślał w czasie rozmowy jaką odbył w Rzymie z abp. Casarolim 10 października 1975 r.: „Sprawa Bpa Tokarczuka i K[adynała]Wojtyły. Obydwaj prowadzą rzetelną robotę Kościoła św. Każda praca, która umacnia Kościól, denerwuje ateistów. Jeżeli Biskup jest zwalczany, to znaczy, że umacnia Kościół"65. Komunistom nie udało się także w 1979 r. przekonać przy pomocy rozmaitych działań, że aktywność bp. Tokarczuka jest szkodliwa dla polskiego Kościoła ${ }^{66}$.

Rządzący PRL wytrzymali stały nacisk biskupów wspomaganych przez szeregowych duchownych i wiernych $\mathrm{w}$ zakresie budownictwa sakralnego (chodzi przede wszystkim o wypowiedzi z ambony i listy kierowane do władz). Ustępstwa w tym zakresie były nieliczne i wymuszone najczęściej przez ryzyko wybuchu niezadowolenia społecznego na szerszą skalę ${ }^{67}$. Prymas wskazywał, że należy władzom nieustanie przypominać o potrzebach budowlanych, gdyż obok nacisku społecznego przynosi to stopniowo pewne efekty ${ }^{68}$, choć jak podkreślał dalekie od oczekiwań i potrzeb Kościoła ${ }^{69}$. To właśnie z inicjatywy kard. Wyszyńskiego powstała nadzwyczajna Komisja Episkopatu Pol-

cy Tokarczuk. Trzeba oprzeć wszystko na prawdzie, [w:] Nigdy przeciw Bogu. Komunistyczna bezpieka wobec biskupów polskich, red. J. Marecki, F. Musiał, Kraków 2007, s. 417-622; P. Chmielowiec, Działania operacyjne Stużby Bezpieczeństwa wobec biskupa Ignacego Tokarczuka i kurii biskupiej w Przemyślu [w:] Aparat bezpieczeństwa wobec kurii biskupich w Polsce, red. A. Dziurok, Warszawa 2009, s. 282-316; Ku prawdzie i wolności. Komunistyczna bezpieka wobec kard. Wojtyty, oprac. M. Lasota, J. Marecki, R. Szczęch, Kraków 2009. Por. M. Lasota, Wspólne drogi kardynała Karola Wojtyły i arcybiskupa Ignacego Tokarczuka, „Studia Rzeszowskie" 2003 (10), s. 67-74.

65 AAG, S. Wyszyński, Pro memoria 1975, zapis z 10 X 1975.

${ }^{66} \mathrm{Na}$ ten temat zob. szerzej, R. Eatka, Dwie wizje roli Kościoła w realiach komunistycznej dyktatury - wymiana korespondencji pomiędzy bp. Ignacym Tokarczukiem ordynariuszem przemyskim a sekretarzem Episkopatu Polski bp. Bronisławem Dąbrowskim w 1979 r., „Dzieje Najnowsze" 2019 nr 1, s. 215-221.

67 Zob. szerzej, R. Gryz, Pozwolić czy nie? Władze PRL wobec budownictwa katolickich obiektów sakralnych w latach 1971-1980, Kielce 2007.

68 AAG, S. Wyszyński, Pro Memoria 1974, zapis z 23 I 1974; AAW, SPP, 04/272, k. 48-49, Protokół KPE z 19-20 VI 1974.

69 AIPSKW, S. Wyszyński, Kazania i przemówienia autoryzowane, t. LI, „Zaplecze normalizacji”. Podczas konferencji diecezjalnych referentów duszpasterstwa, 22 IX 1975, s. 233-234. Zgodnie ze stanowiskiem kard. Wyszyńskiego w samej tylko Warszawie brakowało 50 świątyń, AIPSKW, S. Wyszyński, Kazania i przemówienia autoryzowane, 
ski ds. Budownictwa Kościołów (przekształcona potem w stałą komisję) oraz zainaugurowano coroczny dzień modlitwy w tej intencji w dniu św. Jadwigi, czyli 16 października ${ }^{70}$.

Stopniowo dzięki naciskowi Episkopatu, kierowanego przez prymasa, zmniejszała się liczba kleryków powoływanych do wojska. Przykładowo wg danych przytoczonych w czasie obrad plenarnych Episkopatu Polski z 17-18 listopada 1976 r. z 750 alumnów pierwszego roku WSD powołano do wojska 218, ale na skutek interwencji biskupów zwolniono aż 155, z czego wynika, że do służby trafiło ostatecznie 63 kleryków ${ }^{71}$. Władze z tej uciążliwej dla Kościoła represji zrezygnowały dopiero w $1980 \mathrm{r}^{72}$

Prymas regularnie przypominał władzom o postulatach Kościoła. Przykładowo w homilii wygłoszonej w archikatedrze warszawskiej w styczniu 1978 r. wskazywał czego biskupi domagali się od rządzących PRL: „Episkopat Polski- w swoich rozmowach z władzami postuluję szerszy zakres wolności społecznej, zwłaszcza przywrócenie stowarzyszeń i bractw kościelnych, które działały dawniej. Kościół oczekuję również autentycznej prasy katolickiej i możności wydawania takich książek i wydawnictw, które usprawniłby pracę umoralniającą Naród"73.

Kardynał Wyszyński obszerną ocenę „normalizacji” przedstawił na sesji Konferencji Plenarnej 3-4 października. Można ją traktować jako całościową wizję stosunków wzajemnych sformułowaną tuż przed wyborem na papieża kard. Wojtyły. Na początku prymas wskazał, że władze przekonują, iż proces poprawy stosunków wzajemnych dobiegł końca i rozpoczęła się współpraca, o czym świadczyć miały spotkanie Gierka z kard. Wyszyńskim i wizyta I sekretarza KC PZPR w Watykanie. Dodał, iż część biskupów spodziewała się, że będzie o wiele lepiej, a wspomniany proces realnie poprawi sytuację Kościoła. Prymas stwierdził: „Obiektywnie jednak rzecz biorąc, jakieś osią-

t. LIII, „Odstąpcie od tych ludzi i puśćcie ich”. Podczas uroczystego położenia kamienia węgielnego pod budowę świątyni „Opatrzności Bożej”, 30 IV 1976, Warszawa, s. 279.

${ }^{70}$ R. Eatka, Episkopat Polski..., s. 134 i n.

${ }^{71}$ AAW, SPP 04/284, k. 69, Protokół KPE 17-18 XI 1976.

${ }^{72}$ R. Łatka, Polityka władz PRL wobec Kościoła katolickiego w województwie krakowskim w latach 1980-1989, Kraków 2016, s. 129.

${ }^{73}$ S. Wyszyński, Duch Ewangelii w organizacji życia społeczno-zawodowego i publicznego w Polsce. Do wiernych w archikatedrze warszawskiej, 6 I 1978, Warszawa [w:] idem, Nauczanie społeczne..., s. 804. 
gnięcia są, oczywiście moralne, częściowo nawet polityczne - choćby to, że dziś władze muszą uznać autorytet społeczny Kościoła, muszą się zgodzić, że Kościół zabiera głos w sprawach społecznych i ma tu wiele do powiedzenia. Nie znaczy to, że jest już dobrze, bo zwykle te pewne drobne ustępstwa odrabiają sobie wzmożoną, choć zakamuflowaną akcją laicyzacji społeczeństwa, co w skutkach jest groźniejsze niż głośne akcje, gdyż te ostatnie łatwiej są widzialne i budzą sprzeciw. Władza ludowa wie, że dziś walka z Kościołem zniechęciłaby ludzi - stąd ataki na Kościół są mniejsze, przynajmniej nie słyszy się, że Kościół jest siłą reakcyjną"74. Dodał, że Kościół świadomie nie chce się wiązać ani identyfikować $z$ organizacjami walczącymi o sprawy społeczne, „choć obiektywnie trzeba przyznać rację walce o nie. Te grupy i ten styl walki jest przejściowy, Kościół patrzy szerzej i dalej i ma swój własny styl obrony człowieka"75. W dalszej części referatu kardynał wskazał, że Kościół liczy się z realiami i spokojnie, rozważnie analizuje sytuację społeczno-polityczną, a największe znaczenie wciąż mają status prawny i byt publiczny Kościoła w Polsce, choć władze nie są skłonne do ustępstw ${ }^{76}$.

Sytuacji w zakresie relacji państwo-Kościół nie zmienił ani wybór kard. Wojtyły na papieża, ani jego pierwsza pielgrzymka do Polski, mimo nadziei ze strony kościelnej na pewne przynajmniej korekty w polityce wyznaniowej ${ }^{77}$. Rzeczywiste zmiany w zakresie relacji państwo-Kościół przyniosły dopiero wydarzenia z sierpnia $1980 \mathrm{r}^{78}$.

74 AAW, SPP, 04/293, k. 33, Protokół KPE, 3-4 X 1978.

75 Ibidem, k. 33.

76 Ibidem, k. 34.

77 Co ciekawe prymas Wyszyński jasno wskazywał, że po papieskiej wizycie władze nie tylko nie pójdą na ustępstwa, ale co więcej będą poszukiwać nowych metod zwalczania Kościoła. Zob. szerzej, R. Łatka, Zwycięstwo Kościoła. Prymas Tysiq̨clecia o pierwszej papieskiej pielgrzymce po Polsce, ,Biuletyn IPN” 2017 nr 6, s. 151-152.

78 R. Eatka, Episkopat Polski..., s. 399. 


\section{Nowelizacja konstytucji PRL}

S. Wyszyński, obrady KPE z 18-19 II 1976:

Zasadniczy jej błąd [nowelizacji] tkwi w tym, że Naród, który jest suwerennym, nie może zobowiązywać konstytucyjnie drugiego narodu do przyjaźni i wspótpracy, bo on jest także suwerennym ${ }^{79}$

W 1975 r. dla rządzących ważną kwestią było stworzenie projektu zmian w Konstytucji PRL. Opracowywane poprawki miały charakter ideologiczny i miały m.in. potwierdzić zależność od Związku Sowieckiego. Kościół od początku interesował się działaniami władz w tej sferze ${ }^{80}$. Temat ten pojawił się na forum Rady Głównej Episkopatu w listopadzie 1975 r. Zreferował go prymas, który dość jednoznacznie wskazał: „Projekty idą w kierunku totalizmu i dominacji partii komunistycznej jako przewodniej siły narodu”. Polecił, by Sekretariat Episkopatu przygotował krytykę wytycznych na VII Zjazd PZPR, w których przedstawiono, jak ma wyglądać nowelizacja ustawy zasadniczej ${ }^{81}$. Zajął się tym bp Dąbrowski, który zamieścił wiele negatywnych uwag dotyczących planowych poprawek. Wytknął ich ogólnikowość, wieloznaczność, wzajemną sprzeczność oraz programowanie we wszystkich dziedzinach życia społecznego ideologii marksistowsko-leninowskiej ${ }^{82}$.

Episkopat nie poprzestał na krytyce wytycznych, ale stworzył całościowy memoriał odnoszący się do przygotowywanych poprawek do konstytucji. Kwestię tę kard. Wyszyński omówił na spotkania z bp. Dąbrowskim i ks. Orszulikiem 3 stycznia 1976 r. Przedstawił założenia do głównych tez

79 AAW, SPP 04/280, k. 72, Protokół KPE, 18 i 19 II 1976.

80 Władze za pomocą aparatu bezpieczeństwa zbierały wszelkie komentarze hierarchów i szeregowych duchownych odnoszące się do poprawek do konstytucji i ich opinii na temat reakcji społecznych, AIPN, 0639/136, t. 1-5.

81 AAW, SPP, 04/30, Rada Główna Episkopatu Polski 1975, k. 105, Protokół RG EP, 18 XI 1975.

82 Uwagi sekretarza Episkopatu bp. B. Dąbrowskiego do wytycznych Komitetu Centralnego na VII Zjazd PZPR, 25 XI 1975, Warszawa [w:] P. Raina, Kościół w PRL. Kościół katolicki a państwo w świetle dokumentów 1945-1989, t. 3: Lata 1975-1989, Poznań-Pelplin, 1996, s. 16. O zastrzeżeniach Kościoła dotyczących zmian w konstytucji opartych na zjazdowych wytycznych informowano Sowietów, R. Łatka, Episkopat Polski..., s. 279. 
planowanego dokumentu. Podkreślił, że władze powinny wziąć pod uwagę wcześniejsze memoriały Episkopatu, gdyż biskupi, duchowieństwo i wierzący nie przestają być obywatelami i mają swoje prawa. Dodał, iż państwo musi się troszczyć o zachowanie praw osoby, respektować prawo narodu i państwa do zachowania pełnej suwerenności, a „Kościół, zrośnięty z narodem przez wspólne dzieje, służbę i zasługi, ma korzystać z odpowiedniego szacunku i poszanowania jego misji"83. Wskazania te są o tyle istotne, że w całości znalazły się w ostatecznej wersji memoriałów z 9 stycznia i 26 stycznia 1976 r., co dowodzi, iż ich głównym autorem był kard. Wyszyński (wspomagany przez bp. Dąbrowskiego i ks. Orszulika) ${ }^{84}$.

W protokole posiedzenia RG odnotowano, że Prymas „charakteryzuje sytuację, jaka powstała w związku z zapowiedzianymi w sejmie przez posła Babiucha zmianami w konstytucji. Niepokoi pośpiech, a także ujawnione tendencje do wpisania w konstytucję kierowniczej roli partii w narodzie, sojuszu z ZSRR oraz przynależności Polski do bloku państw socjalistycznych. Niepokoi to społeczeństwo polskie, musi niepokoić Episkopat, gdyż te tendencje prowadzą niedwuznacznie do wyniesienia ideologii partii do ideologii

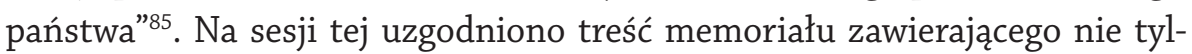
ko zastrzeżenia do nowelizacji ${ }^{86}$, ale również odniesienia do innych kwestii. Prymas stwierdził: „Chcemy, żeby władze miały świadomość, co nas razi i co nas niepokoi, oraz formułujemy zasady, które są bezwzględnie konieczne dla życia każdego normalnego społeczeństwa. Memoriał ma szersze wymiary niż nasze nadzieje na pozytywne załatwienie przedłożonych postulatów"87. 16 stycznia prymas spotkał się z Kazimierzem Kąkolem, który dość pozytywnie odniósł się do pierwszego z memoriałów skierowanych do sejmu i ka-

83 AAG, S. Wyszyński, Pro memoria 1976, zapis z 3 I 1976. Zob. także AIPN, 0639/136, t. 3, k. 105-107, Stenogram wystąpienia kard. Wyszyńskiego na kongregacji księży dziekanów diecezji gnieźnieńskiej (podsumowanie), 22 IV 1976,

${ }^{84}$ AAW, SPP, 04/279, k. 71-72, Protokół KPE, 18-19 II 1976.

${ }^{85}$ AAW, SPP, 04/31, Rada Główna Episkopatu Polski 1976, k. 6, Protokół RG EP, 8 I 1976.

${ }^{86}$ AAG, S. Wyszyński, Pro memoria 1976, zapis z 9 I 1976 r.

87 AAW, SPP, 04/31, Rada Główna Episkopatu Polski 1976, k. 6-7, Protokół RG EP, 8 I 1976. 
zania, które w tej sprawie kard. Wyszyński wygłosił w kościele św. Krzyża ${ }^{88}$. Dokument nie doczekał się odpowiedzi, ale bp Ignacy Tokarczuk uznał, że zarówno wcześniejsza krytyka wytycznych KC PZPR, jak i treść dokumentu wpłynęły na wprowadzenie zmian do poprawek ${ }^{89}$.

Nowelizację Konstytucji PRL uchwalono 10 lutego. Prymas oglądał transmisję z obrad sejmu, przebywając w Choszczówce, i uznał ten obraz za „bardzo bolesny”. Dodał: „Najtrudniej było sformułować sprawę przyjaźni z ZSRR gdyż jest to element obcy dla prawa konstytucjonalnego. Nie można nawet usprawiedliwić go marksizmem, gdyż doktryna ta nie przewidziała takich sytuacji. [...] Zapewne wiele elementów wyretuszowano, licząc się z opinią publiczną. Ale w sumie wszystko to nie wypadło poważnie. [...] Tylko p. K[onstanty] Łubieński zachował się godnie. Ale lepiej p. Stomma, który jeden wstrzymał się od głosowania"90. Kardynał docenił odwagę wieloletniego lidera środowiska „Znaku”, któremu pogratulował z tej okazji 30 marca w specjalnym liście ${ }^{91}$.

Presja Episkopatu przyniosła konkretny efekt, gdyż niektóre zapisy konstytucji zmieniono w pożądanym przezeń kierunku' ${ }^{92}$. Przede wszystkim zrezygnowano z uzależnienia praw obywatelskich od wypełniania obowiązków wobec państwa ${ }^{93}$. Wiele poprawek w przygotowanej nowelizacji dokonano po myśli biskupów, gdyż - jak odnotował kard. Wyszyński w dzienniku - „zdaniem p. Kani tow. Gierek nie chce zatargu z Kościołem, który ma w Polsce swoje zasługi"94. Kardynał Wyszyński podkreślił, że redakcja końcowa nowe-

88 Sprawozdanie z rozmowy z min. Kąkolem w dniu 14 stycznia 1976 [w:] P. Raina, Rozmowy z władzami PRL. Arcybiskup Dąbrowski w służbie Kościoła i narodu, t. 1: 1970-1981, Warszawa 1995, s. 242; AAG, S. Wyszyński, Pro memoria 1976, zapis z 16 I 1976.

89 AIPN, 0639/136, t. 2, k. 15, Meldunek kpt. Stanisława Dzioka, naczelnika Wydziału IV KW MO w Rzeszowie, do naczelnika Wydziału IV Departamentu IV MSW w Warszawie, 21 I 1976, Rzeszów.

90 AAG, S. Wyszyński, Pro memoria 1976, zapis z 10 II 1976. Na temat stanowiska Stommy i powodów, dla których wstrzymał się od głosu, zob. szerzej R. Ptaszyński, Stommizm. Biografia polityczna Stanisława Stommy, Kraków 2018, s. 497-500.

${ }^{91}$ Ibidem, s. 503.

92 AAG, S. Wyszyński, Pro memoria 1976, zapis z 17 II 1976; AAW, SPP, 04/31, Rada Główna Episkopatu Polski 1976, k. 43, Protokół RG EP, 27 IV 1976; AIPN, 0639/136, t. 3, k. 107, Stenogram wystąpienia kard. Wyszyńskiego na kongregacji księży dziekanów diecezji gnieźnieńskiej (podsumowanie), 22 IV 1976.

93 A. Dudek, R. Gryz, Komuniści i Kościół..., s. 335-336.

${ }_{94}$ AAG, S. Wyszyński, Pro memoria 1976, zapis z 6 II 1976. 
lizacji „jest mniej demagogiczna i dostarcza argumentów do obrony praw Kościoła i poszczególnych obywateli. Zasadniczy jej błąd tkwi w tym, że naród, który jest suwerenny, nie może konstytucyjnie zobowiązywać drugiego narodu do przyjaźni i współpracy, bo jest on także suwerenny" ${ }^{\text {95 }}$. Niewątpliwie tego typu ocena (obok innych ustępstw władz) przyczyniła się do poprawy odbioru postaci E. Gierka przez prymasa i miała doprowadzić do ich pierwszego spotkania w $1977 \mathrm{r}$.

\section{Wydarzenia z czerwca 1976 r.}

Z protokołu obrad KPE, 8-9 IX 1976: Zdaniem Księdza Prymasa Kościót musi stawać po stronie pokrzywdzonych robotników i bronić ich praw. [...] W wypadkach radomskich i warszawskich zawiniły władze, gdyż działały zaskakujaco i nie uprzedziły społeczeństwa ${ }^{96}$.

Niezwykle istotny wpływ na rzeczywistość polityczną PRL miał Czerwiec '76, gdy robotnicy wystąpili przeciwko ekipie rządzącej. Ich bunt przyczynił się do odwołania zapowiedzianej podwyżki cen oraz powstania jawnych organizacji opozycyjnych, takich jak Komitet Obrony Robotników, Ruch Obrony Praw Człowieka i Obywatela, Ruch Młodej Polski, Konfederacja Polski Niepodległej, które otwarcie kontestowały realia PRL, domagając się zmian politycznych ${ }^{97}$. W tej sytuacji Kościół przestał być jedynym przeciwnikiem komunistów, którą to funkcję pełnił właściwie od końca lat czterdziestych, gdy zniszczono oddziały podziemia niepodległościowego.

Wydarzenia, które rozegrały się pod koniec czerwca 1976 r. były dla Episkopatu i kard. Wyszyńskiego zaskoczeniem, choć biskupi mieli świadomość, że sytuacja ekonomiczna państwa jest tragiczna ${ }^{98}$. Prymas reakcje na posunięcia władz opisał w Pro memoria 25 czerwca: „Powrót do domu. Tutaj

95 AAW, SPP, 04/279, k. 72, Protokół KPE, 18-19 II 1976.

96 AAW, SPP 04/283, k. 85, Protokół KPE 8-9 IX 1976.

97 Na ten temat zob. szerzej, P. Sasanka, Czerwiec 1976. Geneza, przebieg, konsekwencje, Warszawa 2006; J. Eisler, „Polskie miesiace” czyli kryzys(y) w PRL, Warszawa 2008, s. 44 in.

98 Kardynał Wyszyński już na początku 1975 r. podkreślał, że sytuacja społeczno-gospodarcza stale się pogarsza i może to rzutować na całe polskie społeczeństwo, AAW, SPP 04/30, Rada Główna Episkopatu Polski 1975, k. 6, Protokół KG EP z 14 I 1975. 
«bombowe wiadomości». Pan premier Jaroszewicz, który wczoraj obszernie uzasadniał konieczność podwyższenia cen na artykuły spożywcze, dziś wszystko odwołuje, jakoby w konsultacji ze związkami zawodowymi i licznymi listami napływającymi do rządu. Chodzi struty, że świat robotniczy, który sprawuje rządy w Polsce, burzy się przeciwko rządowi robotniczemu. [...] Konsultacja nie wypadła dobrze. $Z$ tego wstępnego wynika felix culpa, że społeczeństwo polskie zaczyna myśleć o tym, co ignoranci robią z ekonomią narodową" 99 .

Po raz kolejny kard. Wyszyński do wydarzeń, a także do wieców poparcia zorganizowanych na polecenie E. Gierka odniósł się 1 lipca: „Na froncie rewolucji czerwcowej trwa nadal montowanie kłamstwa. Wszyscy na wiecach są zachwyceni podwyżkami i milcząco, ponuro popierają politykę tow. Gierka. O p. Jaroszewiczu cicho, jak w grudniu 1970 r. było cicho o p. Cyrankiewiczu. Partia robi swoje, a odpowiedzialność zrzuca na rząd. Coraz pełniejsze są wiadomości o Radomiu i Ursusie. Napełnia to niepokojem. Świadczy o tym, że w partii jest partia albo kryje się tam kontrrewolucja. [...] Min[ister] Kąkol przyznaje, że rząd popełnił wiele błędów. Oby to uczyniono publicznie, a nie pokątnie. Spowiedź zawsze uspokaja sumienie ludzi i społeczeństwa"100. Prymas w czasie kolejnych miesięcy kilkukrotnie komentował słabość gospodarczą systemu politycznego PRL wynikiem, której był wspomniany wyżej kryzys ustrojowy. Najbardziej wymowna jest jego notatka sporządzona w czasie lipcowego urlopu w Fiszore: „«Szewc bez butów». - Polska - kraj bu-

99 AAG, S. Wyszyński, Pro memoria 1976, zapis z 25 VI 1976. Dwa dni później prymas zauważył, że niedługo może zabraknąć miesięcy na określenie „wszystkich małych rewolucji przed ostateczną katastrofą", ibidem, zapis z 27 VI 1976. Szerzej na temat reakcji biskupów i duchowieństwa na podwyżkę cen zob. AIPN, 0639/146, t. 6, Departament IV MSW, Tezy, 1972-1976, k. 65-80, Tezy dotyczące postawy hierarchii i kleru katolickiego oraz środowisk katolików świeckich w związku z proponowaną podwyżką cen, 12 VII 1976, Warszawa.

100 AAG, S. Wyszyński, Pro memoria 1976, zapis z 1 VII 1976. Prymas pisał o tym bardzo dobitnie i w nietypowy dla siebie emocjonalny sposób: „Zgwałcono robotników, by wielbili przestępców. Krzyczano na cześć p. Gierka. Niektórzy chcieli przekrzyczeć na cześć p. Jaroszewicza. Ale wychodziło blado. Sam p. Jaroszewicz siedział za stołem prezydialnym, jak Judasz w «Ostatniej Wieczerzy» Leonardo da Vinci. Przyglądają się krzyczącym do białej gorączki, nazywam to «Samogwałtem społecznym», ibidem, zapis z 2 VII 1976. 
raka cukrowego - bez łyżeczki cukru dla dzieci. Biada narodowi, gdy jedynym dysponentem jest Państwo; wtedy między nim a łyżeczką cukru dla obywatela- staje urzędnik monopolistyczny"101.

W czerwcu 1976 r., podobnie jak w czasie poprzednich kryzysów ustrojowych, rola Kościoła była kluczowa ${ }^{102}$. Po zakończeniu strajku robotników biskupi kilkakrotnie interweniowali w obronie represjonowanych, np. 16 lipca Episkopat wysłał do premiera Jaroszewicza z postulatem, by zaprzestania działań przeciwko nim ${ }^{103}$, trzy dni później prymas wystosował do Edwarda Gierka list, w którym zdecydowanie skrytykował politykę ekonomiczną i społeczną rządu ${ }^{104}$, a 20 lipca bp Dąbrowski rozmawiał z. Kanią ${ }^{105}$. Żadna z tych nieoficjalnych interwencji nie dała efektu, wobec czego Episkopat ponowił swoje apele publicznie - w komunikatach z września i listopada 1976 r. ${ }^{106} \mathrm{Jak}$ pisali biskupi w pierwszym $\mathrm{z}$ nich: „Uczestniczącym w tych protestach robotnikom trzeba by przywrócić odebrane prawa, pozycję społeczną i zawodową. Wyrządzone krzywdy odpowiednio wynagrodzić, a wobec skazanych zastosować amnestię"107. Naciski Kościoła w połączeniu z innymi czynnikami ostatecznie odniosły skutek - w 1977 r. ogłoszono amnestię i zwolniono skaza-

101 Ibidem, zapis z 6-10 VII 1976.

102 J. Eisler, „Polskie miesiace”..., s. 157-160; P. Raina, Kardynał Wyszyński. Czasy prymasowskie 1976, Biała Podlaska - Warszawa 2010, s. 92-115; M. Białkowski, Prymas Stefan Wyszyński a opozycja demokratyczna (1976-1980). Kilka uwag wstępnych [w:] Stefan Wyszyński wobec opozycji i oporu społecznego 1945-1981, red. E. Czaczkowska, Warszawa 2018, s. 58-59.

103 AAW, SPP, 04/284, k. 53, Protokół KPE, 17-18 XI 1976; List Konferencji Episkopatu Polski do Piotra Jaroszewicza, prezesa Rady Ministrów, 16 VII 1976 [w:] P. Raina, Kardynał Wyszyński. Czasy prymasowskie 1976..., s. 108-111.

104 AAG, S. Wyszyński, Pro memoria 1976, zapis z 12 VII 1976; ibidem, zapis z 15 VII 1976; A. Dudek, R. Gryz, Komuniści i Kościół..., s. 336.

105 Sprawozdanie z rozmowy z p. Stanisławem Kanią, sekretarzem KC PZPR, w Sulejówku dn. 20 lipca 1976 [w:] P. Raina, Rozmowy z władzami PRL..., t. 1, s. 260-264. Zob. także J. Eisler, Siedmiu wspaniałych. Poczet pierwszych sekretarzy KC PZPR, Warszawa 2014, s. 335-336.

106 P. Raina, Kardynał Wyszyński. Czasy prymasowskie 1976..., s. 116-118.

107 Komunikat 154 Konferencji Plenarnej Episkopatu Polski, 10 IX 1976, Jasna Góra [w:] Komunikaty Konferencji Episkopatu Polski 1945-2000, oprac. J. Żaryn, Warszawa-Poznań 2006, s. 177. 
nych za udział w protestach. Stanisław Kania potwierdził, że doszło do tego właśnie w wyniku interwencji prymasa ${ }^{108}$.

Mimo zdecydowanej postawy Kościoła władze nie zaostrzyły polityki wyznaniowej, co więcej, Edward Gierek już dwa miesiące po protestach czerwcowych - 5 września - w publicznym przemówieniu w Mielcu podkreślił: „[istnieje] szerokie pole współdziałania Kościoła i państwa w realizacji ważnych celów narodowych. [...] i widzę w tym współdziałaniu wielki sens. Jest to zresztą nie tylko moje osobiste stanowisko, ale to również stanowisko Biura Politycznego KC naszej partii i stanowisko naczelnych władz naszego państwa"109. Deklaracja ta miała jednakże charakter czysto propagandowy, gdyż władze nie miały zamiaru iść na większe ustępstwa wobec Kościoła. Dostrzegał to prymas, który odnosząc się do słów Gierka stwierdził, iż nie ma ona pokrycia oraz, że władze w dalszym ciągu prowadzą (i będą prowadzić) walkę ideologiczną z Kościołem ${ }^{110}$.

W podsumowaniu 1976 r. prymas zaznaczał, że wydarzeń z czerwca można było uniknąć. Dodawał również, iż: „Bądź co bądź była to jeszcze jedna rewolucja przeciwko Braciom koministom, którzy chcą rządzić Narodem wbrew Narodowi. Rząd «robotniczy» jest zwalczany najsilniej przez Robotników. Istny paradoks. Ale zrozumiały. Bo «robotnik» nie przestał być Człowiekiem, i dopomina się o swoje prawa, nie tylko ekonomiczne, ale społeczne. Kościół w Polsce, w b.r. musiał stawać wyraźnie w obronie Robotników i ludzi uciskanych przez system gospodarki kapitalistycznej, uprawiany przez marksistów"111.

108 AAG, S, Wyszyński, Pro memoria 1977, zapis z 19 VII 1977; A. Dudek, R. Gryz, Komuniści i Kościół..., s. 336-337; P. Sasanka, Czerwiec 1976..., s. 393-395.

${ }^{109}$ Cyt. za A. Dudek, R. Gryz, Komuniści i Kościót..., s. 339.

110 AAW, SPP 04/283, k. 83, Protokół KPE 8-9 IX 1976.

111 AAG, S. Wyszyński, Pro memoria 1976, zapis z 31 XII 1976. 


\section{Stosunek do powstania i działalności opozycji przedsierpniowej ${ }^{112}$}

Stefan Wyszyński, 20 V 1976:

P[anowie] Kuroń i Michnik - omawiaja metody swej pracy. Oceniam je krytycznie. Jestem zdania, że nie wystarczy mówić «nie tak», ale trzeba powiedzieć „jak lepiej”113.

Na sesji Rady Głównej Episkopatu z 26 kwietnia 1976 r., odnosząc się do różnic zdań poszczególnych środowisk na temat zmian w konstytucji i sporów wśród katolików świeckich, prymas sprecyzował pogląd na stosunek Kościoła do polityki: „nasze działanie musi być przemyślane, dojrzałe i spokojne. Nie możemy ad pari ustawiać się z taką czy inną instytucją świecką czy ośrodkiem politycznym. Inaczej mogą to czynić świeccy, a inaczej biskupi. Nie możemy ulegać naciskom ludzi skłóconych i dążących do wykazania swoich racji"114. Tak kardynał odnosił się do powstałych po 1976 r. organizacji opozycyjnych ${ }^{115}$. Swoją myśl kardynał Wyszyński powtórzył na posiedzeniu RG 7 marca 1978 r., gdy omawiano sytuację społeczno-polityczną w obliczu stale pogarszającej się kondycji ekonomicznej państwa. W protokole znalazł się następujący fragment: „Stwierdzono, że są silne naciski na Kościół z różnych stron i próba wciągnięcia go w swoje rozgrywki. Jest duże uaktywnienie niektórych grup katolików świeckich niezrzeszonych. Podobnie Polskie Porozumienie Niepodległościowe zajmuje się Kościołem. Nie możemy pozwolić się wciągnąć w ich aktywizację polityczną, ale z drugiej strony nie możemy ich zwalczać - Kościołowi i naro-

112 Na temat stosunku Kościoła do opozycji przedsierpniowej zob. szerzej, A. Anusz, Przytulisko. Kościół katolicki wobec opozycji politycznej w Polsce w latach 1976-1980, Warszawa 2001; A. Dudek, Kościół i opozycja demokratyczna w Polsce (1976-1989) [w:] Kościót katolicki wczoraj i dziś, red. M. Drzonek et al., Szczecin 1998, s. 75-82; J. Żaryn, Kościót katolicki - hierarchia, kapłani, świeccy [w:] Między Warszawa a regionem. Opozycja przedsierpniowa na Pomorzu Zachodnim, red. M. Kowalczyk, M. Paziewski, M. Stefaniak, Szczecin 2008, s. 19-31; M. Białkowski, Prymas Stefan Wyszyński a opozycja..., s. 51-75; R. Łatka, Rada Główna Episkopatu Polski wobec przedsierpniowej opozycji (1976-1981), „Pamięć i Sprawiedliwość" 2017, nr 1, s. 110-136.

113 AAG, S. Wyszyński, Pro memoria 1976, zapis z 20 V 1976.

114 AAW, SPP, 04/31, Rada Główna Episkopatu Polski 1976, k. 43, Protokół RG EP, 26 IV 1976.

115 Zob. szerzej J. Żaryn, Dzieje Kościoła..., s. 378-400; A. Dudek, R. Gryz, Komuniści i Kościót..., s. 336-340. 
dowi one nie szkodzą, byleby tylko działały umiarkowanie, by nie przekroczyły limitu bezpieczeństwa. [...] Musimy bronić Kościoła, ale też musimy się bronić, by naród nie stanął w sytuacji trudnej. Co zyskamy, gdyby odszedł Gierek? Nieustannie stajemy wobec tylu niewiadomych"116. Postępowanie Kościoła wobec organizacji opozycyjnych w latach 1976-1980 prymas opisał na posiedzeniu RG 26 lutego 1980 r.: „należy ich otoczyć jakąś opieką, nie angażując się w ich kontestację"117. Powtarzał też, iż wobec zachodzących w kraju wydarzeń „trzeba zachować dużo spokoju, żeby nie podsycać napięć”118.

Jak wynika z powyższych wypowiedzi, kardynał postrzegał sytuację z szerokiej perspektywy. Uwzględniał przede wszystkim interes społeczeństwa, a ponadto realia geopolityczne, samej opozycji zaś nie uważał za czynnik szczególnie istotny ${ }^{119}$. Wynikało to również po części z przekonania, że organizacje opozycyjne nie mają poparcia społecznego ${ }^{120}$. Jak trafnie zauważył Andrzej Czuma, współzałożyciel ROPCiO: „Kardynał nie pokładał nadziei w tym, że grupy opozycyjne przyjmą jakąś stałą i rozwijającą się formę. Patrzył na nie z zadowoleniem, ale jednocześnie sceptycznie. Radził katolikom trzymać się Kościoła, wspierać go, a nie wchodzić w działalność tych grup.

${ }^{116}$ AAW, SPP, 04/33, Rada Główna Episkopatu Polski 1978, k. 110, Protokół RG EP, 7 III 1978. Takie stanowisko prymasa potwierdzają jego Pro memoria, np. zapis z 6 kwietnia 1977 r. dotyczący rozmowy z Romualdem Kukołowiczem, P. Raina, Kardynał Wyszyński. Czasy prymasowskie 1977, Warszawa-Biała Podlaska 2010, s. 33-34; czy zapis z 8 czerwca, gdy kard. Wyszyński odnotował odnosząc się do spotkania bp. Dąbrowskiego z kierownikiem UdsW: „Min[ister] Kąkol zadowolony, że nie przyjąłem jako asystentów na Procesję Bożego Ciała Panów Cywińskiego i Mazowieckiego. Zgłaszał ich ks. prałat J. Zalewski. Zapytałem wtedy, czy idzie im o większą Chwałę Chrystusa Eucharystycznego, czy też o swoją chwałę. Mają skłonność do ekshibicji politycznej. Nie zgodzę się na to, by z racji Uroczystości Bożego Ciała, ktoś pobierał «procent chwały» - dla siebie", AAG, S, Wyszyński, Pro memoria 1977, zapis z 8 VI 1977.

117 J. Żaryn, Dzieje Kościoła..., s. 398. W notatce ze swojego dziennika z 5 marca 1978 r. prymas podkreślał: „Episkopat docenia znaczenie ruchów kontest[acyjnych], gdyż nie czuje się sam w walce o prawa osoby ludzkiej; nadto ma możność weryfikować swoje postawy", cyt. za P. Raina, Kardynał Wyszyński. Czasy prymasowskie 1978, Biała Podlaska - Warszawa 2010, s. 29.

118 AAG, S. Wyszyński, Pro memoria 1977, zapis z 17 VI 1977.

119 J. Żaryn, Kościót katolicki - hierarchia, kapłani..., s. 19-23.

120 AIPN, 0639/146, t. 6, Departament IV MSW, Tezy, 1972-1976, k. 100, Tezy dotyczące znaczenia i działalności Kościoła, 25 XI 1976 r., Warszawa. 
Wiem, bo nieraz o tym rozmawiałem z prymasem" ${ }^{121}$. Prymas w czasie posiedzenia Rady Głównej Episkopatu z listopada 1976 r. wskazywał też, że Kościół nie ma potrzeby angażować się w akcje KOR mające na celu wsparcie dla prześladowanych robotników, gdyż ma swoje własne sposoby dotarcia do potrzebujących i będzie je w dalszym ciągu prowadzi1 ${ }^{122}$. Zdania nie zmienił również w późniejszym okresie czasu. Przykładowo w homilii skierowanej do młodzieży z 24 grudnia 1978 r. zaznaczał: „Lubię mówić o wartości życia, o wartości i godności człowieka. Czytałem niedawno w pismach KOR-u artykuł, w którym autor stwierdza, że i Kościół zorientował się w sytuacji i przystąpił do walki w obronie podstawowych praw człowieka i obywatela. Zaskoczyło mnie to, bo mnie się wydawało, że co najmniej od 30 lat Kościół w Polsce to robi. Od dwóch tysięcy lat, od momentu Wcielenia Bożego Syna, dokonuję się zbawienie ludzi, rehabilitacja człowieka, nieustanne przypominanie jego praw i obowiązków"123.

Podsumowując toczącą się na posiedzeniu Rady Głównej w czerwcu 1978 r. dyskusję dotyczącą tego, jakie działania Kościół powinien podjąć w sferze politycznej, prymas podkreślił, iż cele Episkopatu to:

„1) zachowanie konsekwentnej linii i postawy świadczącej, że Episkopat jest niezależny, że nie poddał się presji partii,

2) obrona praw ludzkich i obrona ludzi przed naciskami i udrękami, i przymusowym wcielaniem do partii, górników i hutników przed wyzyskiem"124.

Mimo strategicznie nakreślonego wyżej sceptycznego i ostrożnego stosunku do działalności opozycji kard. Wyszyński przyjmował kontestatorów z różnych środowisk, nawet tak dalekich od wiary katolickiej, jak Jacek Kuroń, gdyż chciał poznać ich poglądy w osobistym kontakcie ${ }^{125}$. Mimo to nie

121 Cyt. za E. Czaczkowska, Kardynał Wyszyński..., s. 625.

122 AAW, SPP, 04/31, Rada Główna Episkopatu Polski 1976, k. 88, Protokół RG EP, 16 XI 1976.

123 AIPSKW, S. Wyszyński, Kazania i przemówienia autoryzowane, t. LXI, „Patrzcie ku przyszłości”. Do młodzieży akademickiej podczas „opłatka”, 24 XII 1978, Warszawa, s. 185.

124 AAW, SPP, 04/33, Rada Główna Episkopatu Polski 1978, k. 110, Protokół RG EP, 7 III 1978. Warto dodać, że prymas bronił również działalności tzw. uniwersytetów latających. Zob. szerzej, A. Dudek, R. Gryz, Komuniści i Kościół..., s. 338.

125 A. Friszke, Czas KOR-u. Jacek Kuroń a geneza Solidarności, Kraków 2011, s. 60-62, 412-413; E. Czaczkowska, Kardynał Wyszyński..., s. 626-628; M. Białkowski, Prymas Stefan Wyszyński a opozycja..., s. 64-67. 
miał zamiaru wyrażać oficjalnego wsparcia ani udzielać im wskazówek co do sposobu działania. Ostatni kapelan prymasa ks. Bronisław Piasecki wspominał: „na Miodową przychodzili różni ludzie, którzy chcieli doradzać prymasowi, jak Kościół powinien postępować. Pewnego razu pojawił się Jacek Kuroń, prymas uważnie słuchał, ale nie zadał żadnego pytania. Po półgodzinie podziękował za uwagi. [...] Ale prymas - powtarzam - miał taki styl. Słuchał, czasem pytał, ale głównie milczał. Potem analizował"126. Niewątpliwie kard. Wyszyński z nieufnością podchodził do KOR, gdyż uważał, że część jego liderów nie do końca przezwyciężyła swoją marksistowską przeszłość ${ }^{127}$. Oczywiście nie wszyscy biskupi mieli taki sam jak kardynał pogląd na rolę Kościoła w odniesieniu do środowisk kontestatorskich ${ }^{128}$. Jan Żaryn słusznie zauważył, że stosunek hierarchów do organizacji opozycyjnych był niejednolity, co wynikało z ich doświadczeń, wizji funkcjonowania Kościoła w rzeczywistości społeczno-politycznej, oraz obaw o jego instrumentalizację $e^{129}$.

Prymas był krytycznie ustosunkowany do współpracy duchowieństwa z opozycją, ale równocześnie jej nie zakazywał. Księdzu Dlopolskiemu, który o to pytał, wskazywał: „Radzę prowadzić akcję parafialną, zamiast współpracy z KOR"130. Potwierdzają to także wydarzenia związane z głodówką w kościele św. Marcina w maju 1977 r. ${ }^{131}$, kard. Wyszyński nie popierał tego typu aktywności ${ }^{132}$, ale nie wyciągał również konsekwencji wobec księży, którzy się

${ }^{126}$ B. Piasecki, M. Zając, Prymas Wyszyński nieznany. Ojciec duchowy widziany z bliska, Kraków 2016, s. 93.

${ }^{127}$ P. Raina, Kardynał Wyszyński i Solidarność, Warszawa 2005, s. 91-95; E. Czaczkowska, Kardynat Wyszyński..., s. 627, 683.

128 J. Żaryn, Kościół katolicki - hierarchia, kapłani..., s. 19.

${ }^{129}$ Idem, Dzieje Kościoła..., s. 416-418.

130 AAG, S. Wyszyński, Pro memoria 1976, zapis z 30 XII 1976.

131 Zob. szerzej Opozycja demokratyczna w Polsce w świetle akt KC PZPR (1976-1980), oprac. Ł. Kamiński, P. Piotrowski, Wrocław 2002, s. 110 i n.; A. Anusz, Przytulisko..., s. 104; J. Żaryn, Dzieje Kościoła..., s. 383-384; J. Skórzyński, Głodówka u św. Marcina [w:] Od Piłsudskiego do Wałęsy. Studia z dziejów Polski w XX wieku, Warszawa 2008, s. 441-458.

${ }_{132}$ Podkreślał to jednoznacznie w swoich zapiskach Pro memoria: „Przychodzi wiadomość, że w kościele św. Marcina, w kaplicy św. Franciszka grupa młodzieży, złożona z 4 osób i 2 studentek rozpoczęła głodówkę. Wśród nich p. Cywiński, którego niedawno przekonywałem, że takiej inicjatywy - wątpliwej w skutkach - nie należy prowadzić w świątyni. - Ale ci Panowie są owładnięci swoimi planami, w wykonaniu których nie liczą się z postulatami Kościoła”, AAG, S, Wyszyński, Pro memoria 1977, zapis z 25 V 1977. 
w nią zaangażowali. Kardynał nie miał równocześnie zamiaru zabierać głosu publicznie w tej sprawie, gdyż jak tłumaczył Bohdanowi Cywińskiemu jego głos będzie potrzebny w sprawach o większej randze ${ }^{133}$. Mimo obaw ks. Bronisława Dembowskiego, rektora świątyni, prymas nie miał do niego pretensji, że zgodził się, by protest głodowy zorganizować w kościele. Kardynał nie uległ również naciskom kierownika UdsW Kąkola, który domagał się jego zakończenia ${ }^{134}$. Warto dodać, iż głodujący osiągnęli swój cel - 23 lipca 1977 r. zwolniono więźniów politycznych, w których obronie wystąpili. Prymas nie zakazał też planowanej na październik 1979 r. głodówki w kościele w Podkowie Leśnej - ks. Kantorskiego, proboszcza tej parafii, poprosił tylko, by był bardzo ostrożny ${ }^{135}$.

$\mathrm{Na}$ stosunek biskupów i prymasa do opozycji przedsierpniowej duży wpływ miała także obawa przed instrumentalizacją duszpasterstw akademickich oraz ich wykorzystaniem do celów politycznych. Wynikało to z faktu, że na początku lat siedemdziesiątych stanowiły one wygodną formę kontestacji ustroju oraz bazę, z której rekrutowali się późniejsi aktywni członkowie organizacji dysydenckich ${ }^{136}$. O ryzyku upolitycznienia duszpasterstw na forum Rady Głównej rozmawiano kilkakrotnie, biskupi poruszali tę kwestię aż do połowy lat osiemdziesiątych, mimo że aktywność opozycyjna znajdowała się na marginesie zainteresowań DA. Jak wynika z protokołów RG, jej członkowie zagrożenie to traktowali jednak bardzo poważnie. Wynikało to po części z faktu, iż Kościół, a przede wszystkim kard. Wojtyła i kard. Wyszyński, przywiązywał wielką wagę do kształtowania przez duchowieństwo właściwej postawy młodzieży ${ }^{137}$. Prymas podkreślał m.in., że

133 AAG, S, Wyszyński, Pro memoria 1977, zapis z 28 IV 1977. Należy dodać, że B. Cywiński wziął udział i był jednym z głównych organizatorów głodówki mimo, że prymas jasno mu powiedział, iż jest przeciwny wykorzystywaniu obiektów sakralnych do takich celów, ibidem, zapis z $25 \mathrm{~V} 1977$.

134 AAW, SPP, 04/31, Rada Główna Episkopatu Polski 1976, k. 68, Protokół RG EP, 7 IX 1976; J. Żaryn, Dzieje Kościoła..., s. 384.

135 A. Anusz, Przytulisko..., s. 117-118; J. Żaryn, Dzieje Kościoła..., s. 384-385.

136 J. Żaryn, Kościót katolicki - hierarchia, kapłani..., s. 24-25.

137 R. Łatka, Rada Główna a przedsierpniowa..., s. 126-128; J. Żaryn, Kościół katolicki w PRL - bliżej władzy czy bliżej opozycji? (1976-1981) [w:] idem, Własna i niepodległa. Czyli o Polakach walczacych o swoja Ojczyznę, Warszawa 2020, s. 198-200. 
Warto w tym miejscu dodać, iż w czasie rozmowy z prymasem, Adam Michnik przedstawił kard. Wyszyńskiemu projekt wykorzystania duszpasterstw do zawoalowanej działalności opozycyjnej. Propozycja jednego z liderów KOR-u została odrzucona przez przywódcę polskiego Kościoła, który nie miał zamiaru zgadzać się na upolitycznienie duszpasterstw i ich instrumentalizację $e^{138}$.

\section{Spotkanie na szczycie w 1977 r.}

S. Wyszyński, Pro memoria, notatka z 27 X 1977: Istnieje więc pewnego rodzaju nakaz moralny, by w tak trudnej sytuacji podać rękę człowiekowi, który z dotychczasowych sekretarzy PZPR w swej polityce przejawia najwięcej troski o naród ${ }^{139}$

Prymas już jesienią 1975 i wiosną 1976 r. sugerował, że jest gotowy na rozmowę z I sekretarzem KC PZPR. Dygnitarze partyjni wracali do niej zwłaszcza po Czerwcu '76, ale hierarcha uważał, że ze względu na stan napięcia społecznego nie jest to właściwy moment na spotkanie na szczycie ${ }^{140}$. Kardynał Wyszyński pod koniec września 1976 r. po rozmowie z bp. Dąbrowskim zwracał uwagę na szereg ustępstw władz, jakie miały miejsce we wspomnianym roku: „Ostatni rok dostarczył nam doświadczeń. Bo Rząd wysuwał niedopracowane inicjatywy, które Biskupi krytycznie oceniali w swoich memoriałach. Rząd wycofywał się w części, lub też całkowicie. I tak: 1/ projekt konstytucji - oceniony krytycznie przez Episkopat uległ modyfikacji; 2/ ustawa o reformie wychowania, też uległa zmianie, pod wpływem oceny Episkopatu; 3/ projekt wychowania seksualnego - też uległ zmianie; 4/ nowa reforma rolna - oceniona przez Episkopat - została odłożona; 5/ ostatnia reforma cen i jej następstwa społeczne - została zmodyfikowana. Te ustępstwa Rządu pod wpływem zdecydowanego sprzeciwu Episkopatu - wskazują, że przed komunistami nie należy łatwo ustępować. [...]"141. Prymas doceniał te ustępstwa ze strony władz i można za-

138 J. Żaryn, Kościót katolicki - hierarchia, kapłani..., s. 24-25.

139 AAG, S. Wyszyński, Pro memoria 1977, zapis z 27 X 1977.

140 AAG, S. Wyszyński, Pro memoria 1976, zapis z 27 VII 1976; ibidem, zapis z 9 XII 1976.

141 Ibidem, zapis z 30 IX 1976. 
ryzykować stwierdzenie, iż stały się one powodem jego zgody na spotkanie z E. Gierkiem.

O sprawie tej w grudniu 1976 r. dyskutowali bp Dąbrowski i Stanisław Kania, który przekazał, iż Gierek jest zainteresowany rozmową z prymasem. Jej temat określił następująco: „zasady z myślą o dobru Polski i narodu, a nie detale. Powinno nam zależeć, żeby to pierwsze spotkanie było początkiem dobrego, pokojowego współdziałania, a nie początkiem wojny"142. Ze względu na rozwój sytuacji społeczno-politycznej i późniejszą chorobę kard. Wyszyńskiego do rozmowy nie doszło ani na początku 1977 r., ani wiosną, lecz dopiero $\mathrm{w}$ październiku ${ }^{143}$. Zgodnie z początkowymi ustaleniami spotkanie miało się odbyć 26 października w Choszczówce, gdzie prymas przechodził rekonwalescencję po operacji woreczka żółciowego ${ }^{144}$.

Na skutek nacisków władz, zainteresowanych tym, by miało ono bardziej oficjalny charakter, przeniesiono je do siedziby Rady Państwa, znajdującej się w budynku sejmu, a termin ustalono na 29 października. Początkowo kard. Wyszyński nie chciał przystać na zmianę charakteru i miejsca rozmowy (wg pierwotnych żądań komunistów miał to być sejm), obawiając się, jak odbierze to społeczeństwo ${ }^{145}$. Ostatecznie przystał na tą propozycję kierując się przekonaniem, że należy tak zrobić ze względu na interes ojczyzny: „Ale ta sytuacja E[dwarda] Gierka, chociaż nie jest dla Kościoła w Polsce nagląca, ma doniosłe znaczenie dla polskiej racji stanu. Ale idzie o to, by ją wykorzystać, bo Kościół ma zawsze czas. Ale idzie o to, by zaznaczyć wolę obrony suwerenności narodu. Istnieje więc pewnego rodzaju nakaz moralny, by w tak trudnej sytuacji podać rękę człowiekowi, który z dotychczasowych sekretarzy PZPR w swej polityce przejawia najwięcej troski o naród (rodzina, polityka populacyjna, renty). Ma on swoje błędy, na skutek przeekonomizowania gospodarki narodowej, przerostu inwestycji za pożyczone pieniądze. Ale nie leży w interesie Kościoła w Polsce, by E[dward] Gierek został zniszczony. Bo następcy mogą być gorsi i mogą odrobić posunięcia E[dwarda] Gierka"146.

142 Rozmowa telefoniczna z p. Stanisławem Kaniq, sekretarzem KC PZPR, 9 XII 1976 [w:] P. Raina, Rozmowy z władzami PRL..., t. 1, s. 285-286.

143 P. Raina, Kardynał Wyszyński. Czasy prymasowskie 1977..., s. 160-161

144 Ibidem, s. 145-158.

145 AAG, S. Wyszyński, Pro memoria 1977, zapis z 24 X 1977.

146 Ibidem, zapis z 27 X 1977. 
W materiałach przygotowawczych do spotkania prymas określił główne wątki, które chciał podjąć. Po kurtuazyjnym wstępie zamierzał wspomnieć o kwestiach ogólnonarodowych, wspólnej trosce o ojczyznę, a potem nawiązać do przemówienia wygłoszonego przez Gierka 31 grudnia 1970 r. ${ }^{147}$. Następnie kardynał planował podkreślić, że docenia linię polityczną Gierka w kwestii kontaktów z państwami zachodnimi, oraz zapytać, czy deklaracje I sekretarza KC PZPR dotyczące spraw społecznych są szczere, czy mają tylko służyć uspokojeniu społeczeństwa. Zapisał: „Jeśli słowa nie odpowiadają czynom, może być skutek odwrotny"148. Prymas chciał również wskazać: „Wolność religijna jest komponentem demokracji [...] Boli nas przemilczanie Kościoła w życiu narodu, jego wkładu w kulturę narodową; boli nas wykreślanie Kościoła $\mathrm{z}$ historii, $\mathrm{z}$ informacji, z wszystkich dziedzin współczesnego życia, a więc i radia, TV itp. Kościół nie chce zastępować partii i rządu; nie ma i nie miał nigdy ambicji politycznych. Chce tylko spokojnie pełnić swoją misję ewangeliczną, służyć narodowi"149. Potem zamierzał wymienić mówić o blokowaniu obsady stanowisk kościelnych, konieczności zwolnienia alumnów ze służby wojskowej, nękaniu duchowieństwa przez SB i utrudnianiu Kościołowi działalności społecznej. Planował wspomnieć o dialogu między Stolicą Apostolską a władzami PRL, który powinna poprzedzać normalizacja stosunków rządu i Kościoła w Polsce ${ }^{150}$.

Nie wszystkie planowane wątki prymas poruszył. Zrezygnował m.in. ze szczegółowego omawiania sytuacji Kościoła i postulatów Episkopatu. Na początku zadeklarował, że już od dawna nosił się z zamiarem odbycia tej rozmowy, oraz wskazał jej cele $\mathrm{z}$ własnej perspektywy. Tak opisał to w dzienniku: „Nie mam zamiaru załatwiać spraw ani wysuwać postulatów, nie chcę też oceniać, krytykować lub czegokolwiek żądać. Moja obecność dziś jest podyktowana potrzebami polskiej racji stanu, zwłaszcza na progu uroczystości 60-lecia rewolucji w Moskwie i podróży E[dwarda] Gierka do Rzymu. Wydaje mi się, że w takim układzie spotkanie nasze ma jakiś sens i służy dobrze narodowi. Pragnę, by pan E[dward] G[ierek] wiedział, że uważnie przyglądamy

147 AAW, SPP, Kościół i państwo, t. 23, Punkty do rozmów prymasa Polski (G 26 X 1977 r.), projekt, 23 X 1977 r., s. 1-2.

148 Ibidem, s. 2.

149 Ibidem, s. 3.

150 Ibidem, s. 3-4. 
się jego pracy i znajdujemy korzystne zmiany, chociaż nie brak i trudności, o czym możemy mówić nie dziś - ale może w przyszłym roku"151. Edward Gierek odpowiedział, że cieszą go te intencje oraz możliwość spotkania. Prymas odnotował, że w dyskusji najpierw on sam przedstawiał określone zagadnienia, a następnie odnosił się do nich I sekretarz PZPR. Potem przez 45 minut mówił Gierek, a na koniec obaj wygłosili konkluzje. Prymas poruszył pięć szerokich zagadnień tematycznych: 1) godność narodu i jego prawa, 2) przeekonomizowanie gospodarki, 3) bezpieczeństwo Polski, 4) Kościół i państwo, 5) podróż Gierka do Rzymu i Stolicy Apostolskiej. Najważniejsze ze swojej perspektywy kwestie omówił na początku. Podkreślił: „Wiem, że E[dward] G[ierek] ma myślenie narodowe i jego polityka zmierza do uwydatnienia suwerenności narodu i jego awansu politycznego i społ-[eczno]-gosp[odarczego]. Nas cieszy priorytet życia rodzinnego, złagodzenie akcji błędnej demografii i polityki ludnościowej, próba usamodzielnienia rodziny i stworzenie jej przestrzeni mieszkaniowej"152. Zaznaczył, iż należy zapewnić pokój wewnętrzny w ojczyźnie. Podkreślił konieczność unikania „małych rewolucji”, takich jak w czerwcu 1976 r., dalszego postępu demokratyzacji i rozwiązania problemów zaopatrzeniowych, gdyż to one najczęściej powodują niechęć wobec rządu ${ }^{153}$. W odpowiedzi Gierek wskazał, że jest Polakiem, myśli po polsku i stara się rozwiązywać problemy zaopatrzeniowe, ale nie wszystko da się zrobić od razu. Podkreślił swoją troskę o suwerenność narodu. Następnie kardynał odniósł się także do kwestii ekonomicznych, akcentując brak równowagi w gospodarce i nierównomierny rozwój przemysłu i rolnictwa. Stwierdził, iż państwo powinno się doceniać znaczenie rolnictwa i dbać o nie. Dodać, że Polska wciąż jest zagrożona ze strony Niemiec. Tak prymas opisał dalszą część rozmowy: „E[dward] G[ierek] jest zdania, że trzeba orientować się na sojusze naturalne, by nie być izolowanym. Nie wskazuje z kim, ale się to wyczuwa. Nie trzeba się lękać, ze to pójdzie zbyt daleko. Ja, mówi E[dward] G[ierek], jestem daleki od tego, by Polskę sprzedać komukolwiek. Jestem Polakiem -

151 AAG, S. Wyszyński, Pro memoria 1977, zapis z 29 X 1977; P. Raina, Kardynał Wyszyński. Czasy prymasowskie 1977..., s. 168.

152 AAG, S. Wyszyński, Pro memoria 1977, zapis z 29 X 1977.

153 Ibidem. 
zapala się i nieco unosi. Odpowiadam: jestem przekonany, że E[dward] G[ierek] prowadzi politykę sojuszów i niezależności Polski"154.

Kardynał Wyszyński ocenił spotkanie z I sekretarzem jako „dodatnie”, bez względu na ewentualne krytyczne komentarze, które mogłyby się pojawić w prasie zagranicznej ${ }^{155}$. Na posiedzeniu Konferencji Plenarnej 14-15 grudnia wskazał, że była mowa o sprawach zasadniczych, m.in. problematyce rodzinnej, wsparciu dla wielodzietnych rodzin czy budownictwie mieszkaniowym ${ }^{156}$. Prymas był pod ewidentnym wrażeniem Gierka, doceniał jego otwartość w przedstawianiu problemów społeczno-politycznych. Świadczy o tym zapis w dzienniku sporządzony świeżo po spotkaniu: „Jest to człowiek spokojny, równy, poważny, widocznie zmęczony i blady. Trzyma się prosto. Robi wrażenie szczerego i wolnego od krzywizn taktycznych oraz chwytów słownych. Mówi dobrze, zdania układa poprawnie. Nie ma w słowach nalotu folkloru dębowieckiego. Unika ostrych sformułowań i polemiki. Chociaż swoje oceny wypowiada z przekonaniem. Nie ma też frazeologii marksistowskiej, ani akcentów socjalistyczno-ateistycznych. Jest w nim szacunek dla Kościoła i religii. Przywiązany do Polski i tradycji historycznych. Budzi zaufanie od pierwszego słowa. Oczywista, że zapewne sens naszego spotkania zabarwił styl zachowania i słownik - przebija raczej osobowość, taktyka polityczna. Z moich rozmówców partyjno-rządowych (Bierut, Mazur, Gomułka, Cyrankiewicz, Jaroszewicz) p. E. Gierek przedstawia się najkorzystniej"157. Z tego fragmentu przebija sympatia do I sekretarza KC PZPR. Główną rolę odegrały cechy jego charakteru, który w przeciwieństwie do Gomułki, zachowywał się w spokojny i wyważony sposób, prezentując wysoką kulturę osobistą.

Ocena władz w pewnej mierze pokrywała się z podejściem Episkopatu. Prymas w rozmowie $\mathrm{z}$ Kąkolem 3 listopada miał swoje spotkanie $\mathrm{z}$ I sekretarzem KC PZPR uznać za doniosłe i powiedzieć: „Pan Gierek był miły, niezwykle ujmujący szczerością i zaangażowaniem, ważył słowa ogromnie. Zrozumiałem, że nie jest to moment dla spraw wypadkowych, ale dla podstawowych"158. $\mathrm{Na}$

154 P. Raina, Kardynał Wyszyński. Czasy prymasowskie 1977..., s. 172.

155 AAG, S. Wyszyński, Pro memoria 1977, zapis z 28 X 1977.

156 AAW, SPP, 04/289, k. 46, Protokół KPE, 15-16 XII 1977.

157 P. Raina, Stefan Kardynał Wyszyński. Prymas Tysiaclecia..., t. 4, s. 706-707.

158 AAN, KC PZPR, XIA/800, k. 2, Notatka o przebiegu rozmowy kierownika Urzędu do Spraw Wyznań Kąkola z ks. kard. Wyszyńskim, 3 XI 1977. 
posiedzeniu Rady Głównej 13 grudnia kardynał zaznaczył nawet, iż spotkanie z Gierkiem zarówno w Polsce, jak i w Watykanie miało historyczny charakter i było znaczącym krokiem ku porozumieniu społecznemu ${ }^{159}$. Równie pozytywną ocenę prymas zaprezentował na posiedzeniu Konferencji Plenarnej dzień później. Miał świadomość, iż kontakty z Gierkiem społeczeństwo może uznać za kontrowersyjne, ale uważał, że przed wizytą I sekretarza KC PZPR u Pawła VI były konieczne, by nie wytworzyć wrażenia, iż władze porozumiewają się ze Stolicą Apostolską ponad głowami Episkopatu ${ }^{160}$.

W ścisłym związku z opisanymi dyskusjami, przede wszystkim na forum Rady Głównej, pozostawał wydany 16 grudnia komunikat z obrad plenarnych Episkopatu. Biskupi podkreślili w nim, że relacje państwo-Kościół powinny być oparte na trwałym fundamencie, czyli uznaniu statusu prawnego Kościoła, tak jak przed wojną. Spotkanie prymasa z Gierkiem uznali za doniosłe i stwierdzili, że może się ono przyczynić do pogłębienia pokoju społecznego. Wskazali też motywy prowadzenia dialogu: „Episkopat uważa rozmowy z władzami państwowymi dla dobra narodu i Kościoła za pożyteczne, a nawet konieczne"161. Komuniści ocenili ten komunikat negatywnie, co w głównej mierze wynikało z odwołania się biskupów do okresu przedwojennego ${ }^{162}$; zdaniem biskupów wspomniany dokument oddalił ryzyko obaw społecznych związanych z potencjalnym ryzykiem zbytniego zbliżenia Kościoła do władz PRL ${ }^{163}$.

Nie oznacza to, że kardynał Wyszyński nie wyrażał w tym czasie negatywnych opinii na temat Gierka. Tak opisał rozmowę z Kukołowiczem, który zrelacjonował mu swoje spotkania m.in. z prof. Janem Szczepańskim i Antonim Rajkiewiczem: „Informatorzy p. Gierka mają podobne [krytyczne] oceny co do sytuacji Polski. Ale p. Gierek jest optymistą «referentowym». Przyjmu-

159 AAG, S. Wyszyński, Pro memoria 1977, zapis z 13 XII 1977.

${ }^{160}$ Ibidem, zapis z 14 XII 1977.

161 Komunikat 161 Konferencji Plenarnej Episkopatu Polski, 15 XII 1977, Warszawa [w:] Komunikaty..., s. 191.

162 Szyfrogram ministra spraw zagranicznych oraz członka BP KC PZPR do Szefa Zespołu do spraw Stałych Kontaktów Roboczych ze Stolica Apostolską; instrukcja do rozmowy z sekretarzem Rady do Spraw Publicznych Kościoła, 22 XII 1977, Warszawa [w:] Polskie dokumenty dyplomatyczne 1977, red. P.M. Majewski, współpraca P. Długołęcki, Warszawa 2009, s. 793.

163 Zob. szerzej, R. Łatka, Episkopat Polski..., s. 323-325. 
je tylko dobre naświetlenia, złych i krytycznych nie chce przyjąć. Wzrasta w nim psychoza dobrostanu władzy? To jest nieszczęście. Pytanie - co można powiedzieć panu G[ierkowi]? Właściwie bez odpowiedzi. A jednak trzeba będzie wiele powiedzieć, niezależnie od skutków jakie to wywoła"164. Innym przykładem jest reakcja prymasa na relacjonowane w telewizji przemówienie I sekretarza KC PZPR wygłoszone 31 grudnia 1978 r.: „Fatalny stan pogody określa jako katastrofę żywiołową - ujawnił całą biedę gospodarki państwowej. Bez zaopatrzenia węglowego zostały elektrociepłownie, fabryki, elektrownie i różne instytucje. Rząd musiał odwołać wiele zarządzeń eksportowych, wstrzymać pociągi eksportowe i skierować je do instytucji pierwszej potrzeby. Okazuje się, że cały węgiel szedł na eksport, wskutek tego państwo mające służyć obywatelom zapomniało o ich potrzebach. Także instytucje, które należało zaopatrzyć w paliwo w ciągu dnia, nie miały zapasu na dwa dni mrozu. Oto prawda o kapitalistycznej gospodarce marksistów, dla których obywatel jest tylko od pracy, a o zaspokajaniu potrzeb człowieka pracującego nie myśli ani partia, ani rząd"165.

Spotkanie kard. Wyszyńskiego z E. Gierkiem pokazywało jak w soczewce stosunek prymasa do najważniejszych kwestii z zakresu spraw społeczno-politycznych. Przez jego pryzmat możemy oceniać stosunek tego hierarchy do kwestii takich jak polska racja stanu, czy troska o poszerzenie społecznej wolności. Wreszcie możemy zdobyć się również na stwierdzenie, że z punktu widzenia prymasa wspomniany wyżej I sekretarz KC PZPR był wyborem najmniej złym. Patrząc na to kim byli następcy Gierka i jak zapatrywali się na działalność Kościoła w Polsce trudno ocenie kardynała nie przyznać racji.

164 AAG, S. Wyszyński, Pro memoria 1978, zapis z 20 VI 1978.

165 Ibidem, zapis z 31 XII 1978. 


\section{Wybór Jana Pawła II - kontekst polityczny}

Stefa Wyszyński, notatka z Pro memoria, 16 X 1978 : Krótka rozmowa prywatna z Jego Świątobliwościq. Jesteśmy obydwaj zażenowani tym tytułem, który nagle w ciaggu 2 godzin staną między nami. Ja straciłem wielkiego Przyjaciela i bliskiego Wspótpracownika. - Ale zarazem zyskałem, gdyż nie będę musiał długo tłumaczyć sytuacji K[ościo]ła w P[olsce], gdyż tak dobrze ją zna nowy Papież $\dot{z}^{166}$

Decyzja konklawe z 16 października 1978 r. jest słusznie uznawana za jedno z najważniejszych wydarzeń w dziejach Polski. Jej rangę właściwie przedstawił prymas Stefan Wyszyński w podsumowaniu roku 1978: „Do wymiaru światowego należy bodaj wybór Polaka na Stolicę Piotrową poprzez tajemniczą śmierć dwóch papieży. Polska, tak bardzo krytykowana przez różne państwa (Francja, Belgia, Holandia, Niemcy), stała się nadzieją krajów katolickich ujawnioną w wyborze Polaka na głowę Kościoła - i to takiego Polaka"167.

Komentując tę sytuację na bieżąco, prymas stwierdził, że jest istotne, iż kandydat pochodzi z kraju, który mimo jarzma komunistycznego zachował wiarę, jedność z Kościołem oraz „żywą religijność, którą podziwiało wielu kardynałów świata w Polsce"168. Prymas, w pierwszym przemówieniu po konklawe z 17 października (skierowanym do polskich kapłanów studiujących w Rzymie), podkreślał niezwykłość tego wydarzenia, zwracając uwagę, iż pierwszy raz od czterech wieków papieżem zastał hierarcha z poza Włoch i to z państwa znajdującego się w bloku komunistycznym ${ }^{169}$. Kardynał Wyszyński zwracał też uwagę, że kardynałowie i obserwatorzy zewnętrzni komentując wybór wskazywali „Polsce się to należało”, za wytrwanie przy wierze katolickiej i wierność Stolicy Apostolskiej ${ }^{170}$.

166 Ibidem, zapis z 16 X 1978.

167 P. Raina, 1978. Wybór papieża Jana Pawła II. Zapiski prymasa, Warszawa 2008, s. $181-182$.

168 AAG, S. Wyszyński, Pro memoria 1978, zapis z 16 X 1978.

169 AIPSKW, S. Wyszyński, Kazania i przemówienia autoryzowane, t. LXI, „Pierwsze słowa Prymasa Polski po powrocie do Instytutu z konklawe, na którym kardynał Wojtyła został papieżem". Do kapłanów polskich studiujących w Rzymie, 17 X 1978, Rzym, s. 21-22.

170 Ibidem, s. 22. 
Miesiąc później prymas podkreślał, że wielką zaletą nowej sytuacji jest to, iż Ojcu Świętemu nie trzeba wyjaśniać sytuacji Kościoła w kraju: „Dzisiaj w kontaktach między Polską o Stolicą świętą nie ma już tego wysiłku, na który trzeba było zdobywać się kiedyś, aby należycie wyjaśnić sytuację w jakiej pracuję Kościół w Ojczyźnie naszej"171. Jak trafnie zauważyli Antoni Dudek i Ryszard Gryz, dwa wierzchołki trójkąta PRL - Stolica Apostolska - Episkopat Polski połączył Ojciec Święty, który doskonale orientował się w realiach systemu komunistycznego ${ }^{172}$.

Decyzja konklawe uruchomiła także szereg dalszych wydarzeń. Wśród nich na pierwszy plan z polskiej perspektywy wysuwała się niewątpliwe kwestia przyjazdu Jana Pawła II do Polski już w 1979 r. Bezpośrednio po konklawe zarówno Ojciec Święty jak i polscy biskupi zaczęli w publicznych wypowiedziach wspominać, że możliwy jest przyjazd Ojca Świętego do Polski. Kardynał Wyszyński już 6 listopada 1978 r. w katedrze św. Jana w Warszawie mówił: „Jest nadzieja na to, że Ojciec Święty chce jak najprędzej przybyć do Polski. Najlepszą sposobnością są uroczystości świętego Stanisława w Krakowie, zapowiedziane na 13 maja przyszłego roku. Może przy tej okazji Ojciec Święty zobaczy nie tylko Kraków i Częstochowę. Ale pozwólcie, że jako człowiek dyskretny zamknę usta i nie pozwolę mówić memu sercu, a powierzę te myśli waszym sercom. Co wymodlicie, to będzie zyskiem Kościoła w Polsce i w Rzymie"173. Pod koniec tego miesiąca zaś jasno poinformowano o tym w Komunikacie z posiedzenia Konferencji Episkopatu Polski ${ }^{174}$. Presja Episkopatu przyniosła efekt, gdyż w czasie kolejnego spotkania na szczycie kard. Wyszyńskiego z E. Gierkiem z 24 stycznia 1979 r. władze PRL wyraziły zgodę na przyjazd papieża do Polski ${ }^{175}$.

171 AIPSKW, S. Wyszyński, Kazania i przemówienia autoryzowane, t. LXI, „Na 30-lecie służby Kościołowi Gnieźnieńskiemu", 17 XI 1978, Gniezno, s. 136.

${ }_{172}$ A. Dudek, R. Gryz, Komuniści i Kościół..., s. 310.

173 Cyt. za: R. Łatka, Wstęp [w:] Pielgrzymki Jana Pawła II do Krakowa w oczach SB. Wybór dokumentów, oprac. R. Łatka, Kraków 2012, s. 12

174 J. Żaryn, Dzieje Kościoła..., s. 405.

175 Zob. szerzej, R. Łatka, Rada Główna Episkopatu Polski a pierwsza pielgrzymka Jana Pawła II do Ojczyzny, „Dzieje Najnowsze” 2018 nr 1, s. 236-238. 


\section{Podsumowanie}

Kardynał Wyszyński wykazał się w latach 1974-1978 wybitnym zmysłem politycznym. Nie dał się nabrać na przyjaźnie brzmiące deklaracje władz PRL o dążeniu do normalizacji stosunków wzajemnych, odczytał taktykę dygnitarzy partyjnych, którzy nie mieli zamiaru wprowadzać poważniejszych zmian w polityce wyznaniowej. Równie trafnie prymas odczytywał wydarzenia w sferze społeczno-politycznej. Świadczy o tym dość jednoznacznie jego reakcja na nowelizacje Konstytucji PRL, oraz na wydarzenia z czerwca 1976 r. Wydaję się także, że kardynał zajmując ostrożne i wyważone stanowisko w odniesieniu do działalności opozycji przedsierpniowej miał z punktu widzenia interesów Kościoła i społeczeństwa rację. Dystans wobec ich aktywności zapobiegł zinstrumentalizowaniu duchowieństwa na rzecz organizacji, które nie cieszyły się zbyt szerokim poparciem Polaków.

Nie oznacza to rzecz jasna, że kard. Wyszyński był nieomylny. Wydaję się bowiem, iż uległ w pewien sposób urokowi E. Gierka uważając, że wspomniany I sekretarz KC PZPR może odegrać pozytywną rolę w rzeczywistości społeczno-politycznej PRL. Było to widoczne szczególnie w refleksji po pierwszym spotkaniu z najwyższym rangą przedstawicielem władz, gdy prymas jasno wskazał, że ze wszystkim partyjnych rozmówców Gierek prezentował się najlepiej. Mimo dość pozytywnej oceny jego osoby kardynał potrafił odnosić się krytycznie do błędów jakie jego zdaniem popełniał wspomniany przywódca partyjny. 


\section{BIBLIOGRAFIA}

\section{I. ŹRÓDEA}

\section{Archiwum Akt Nowych}

AAN, KC PZPR, XIA/800.

\section{Archiwum Archidiecezjalne Gnieźnieńskie}

AAG, S. Wyszyński, Pro memoria 1974.

AAG, S, Wyszyński, Pro memoria 1975.

AAG, S. Wyszyński, Pro memoria 1976.

AAG, S. Wyszyński, Pro memoria 1977.

AAG, S. Wyszyński, Pro memoria 1978.

\section{Archiwum Archidiecezjalne Warszawskie}

AAW, SPP 04/29, Rada Główna Episkopatu Polski 1974. AAW, SPP 04/30, Rada Główna Episkopatu Polski 1975. AAW, SPP 04/31, Rada Główna Episkopatu Polski 1976. AAW, SPP 04/32, Rada Główna Episkopatu Polski 1977. AAW, SPP, 04/33, Rada Główna Episkopatu Polski 1978. AAW, SPP 04/272. AAW, SPP, 04/275. AAW, SPP 04/277. AAW, SPP, 04/279. AAW, SPP 04/280. AAW, SPP, 04/283. AAW, SPP, 04/284. AAW, SPP, 04/289. AAW, SPP, 04/293. AAW, SPP, Kościół i państwo, t. 23.

\section{Archiwum Instytutu Pamięci Narodowej.}

AIPN, 02011/535.

AIPN, 0639/136, t. 1-5. AIPN, 0639/146 t. 1-6.

Archiwum Instytutu Prymasowskiego Stefana Kardynała Wyszyńskiego AIPSKW, S. Wyszyński, Kazania i przemówienia autoryzowane, t. XLV. AIPSKW, S. Wyszyński, Kazania i przemówienia autoryzowane, t. XLVI. AIPSKW, S. Wyszyński, Kazania i przemówienia autoryzowane, t. XLVII. AIPSKW, S. Wyszyński, Kazania i przemówienia autoryzowane, t. XLIX. 
AIPSKW, S. Wyszyński, Kazania i przemówienia autoryzowane, t. LI. AIPSKW, S. Wyszyński, Kazania i przemówienia autoryzowane, t. LIII. AIPSKW, S. Wyszyński, Kazania i przemówienia autoryzowane, t. LIV. AIPSKW, S. Wyszyński, Kazania i przemówienia autoryzowane, t. LV. AIPSKW, S. Wyszyński, Kazania i przemówienia autoryzowane, t. LXI.

„Wiadomości Archidiecezjalne Warszawskie” 1974.

„Wiadomości Archidiecezjalne Warszawskie” 1976.

„Wiadomości Archidiecezjalne Warszawskie” 1977.

\section{Dokumenty publikowane}

Friszke A., PRL wobec Kościoła. Akta 1970-1978, Warszawa 2010.

Komunikaty Konferencji Episkopatu Polski 1945-2000, oprac. J. Żaryn, Warszawa-Poznań 2006.

Ku prawdzie i wolności. Komunistyczna bezpieka wobec kard. Wojtyły, oprac. M. Lasota, J. Marecki, R. Szczęch, Kraków 2009.

Listy pasterskie Episkopatu Polski 1945-2000, część I, red. P. Libera, A. Rybicki, S. Łącki, Marki 2003.

Listy pasterskie Prymasa Polski oraz Episkopatu 1975-1981, Paris 1988.

Nigdy przeciw Bogu. Komunistyczna bezpieka wobec biskupów polskich, red. J. Marecki, F. Musiał, Kraków 2007.

Plany pracy Departamentu IV MSW na lata 1972-1979, oprac. M. Biełaszko, A. Piekarska, P. Tomasik, C. Wilanowski, Warszawa 2007.

Pielgrzymki Jana Pawła II do Krakowa w oczach SB. Wybór dokumentów, oprac. R. Łatka, Kraków 2012.

Polskie dokumenty dyplomatyczne 1977, red. P.M. Majewski, współpraca P. Długołęcki, Warszawa 2009.

Raina P., Kościół w PRL. Kościół katolicki a państwo w świetle dokumentów 1945-1989, t. 3: Lata 1975-1989, Poznań-Pelplin, 1996.

Raina P., Rozmowy z władzami PRL. Arcybiskup Dąbrowski w służbie Kościoła i narodu, t. 1: 1970-1981, Warszawa 1995.

Sprawy, które toczq się w Polsce maja znaczenie światowe. Niepublikowane przemówienie Jana Pawła II do Rady Głównej Episkopatu Polski, Jasna Góra, 5 czerwca 1979 r., red. A. Grajewski, Jasna Góra 2019.

Teczki Wojtyty, Warszawa 2003.

W stużbie Boga i Polski. Komunistyczna bezpieka wobec kardynała Stefana Wyszyńskiego, oprac. J. Marecki, P. Nitecki, R. Szczypta-Szczęch, Kraków 2014.

Wyszyński S., Nauczanie społeczne 1946-1981, Warszawa 1990.

\section{Wspomnienia, relacje}

Piasecki B., Zając M., Prymas Wyszyński nieznany. Ojciec duchowy widziany z bliska, Kraków 2016. 


\section{OPRACOWANIA}

Anusz A., Przytulisko. Kościół katolicki wobec opozycji politycznej w Polsce $w$ latach 1976-1980, Warszawa 2001.

Białkowski M., Prymas Stefan Wyszyński a opozycja demokratyczna (1976-1980). Kilka uwag wstępnych [w:] Stefan Wyszyński wobec opozycji i oporu społecznego 1945-1981, red. E. Czaczkowska, Warszawa 2018.

Chmielowiec P., Działania operacyjne Stużby Bezpieczeństwa wobec biskupa Ignacego Tokarczuka i kurii biskupiej w Przemyślu [w:] Aparat bezpieczeństwa wobec kurii biskupich w Polsce, red. A. Dziurok, Warszawa 2009.

Czaczkowska E., Kardynał Wyszyński. Biografia, Kraków 2013.

Dudek A., Kościót i opozycja demokratyczna w Polsce (1976-1989) [w:] Kościół katolicki wczoraj i dziś, red. M. Drzonek et al., Szczecin 1998.

Dudek A., Lawirowanie. Ekipa Gierka wobec Kościoła katolickiego (1971-1978), „Więź” 1997 nr 7.

Dudek A., PRL i Stolica Apostolska 1971-1974, [w:] Społeczeństwo - Państwo - Kościót 1945-2000. Materiały z ogólnopolskiej konferencji naukowej. Szczecin 15-16 VI 2000 r., red. A. Kawecki, K. Kowalczyk, A. Kubaj, Szczecin 2001.

Dudek A., Prymas Stefan Wyszyński wobec władz komunistycznych w latach 1956-1978 [w:] Prymas Stefan Kardynał Wyszyński- świadek Ewangelii i tradycji narodowych. Materiaty sesji naukowej w Wyższym Seminarium Duchownym w Kielcach 19 maja 2001 r., Kielce 2001.

Dudek A., Gryz R., Komuniści i Kościół w Polsce (1945-1989), Kraków 2006.

Eisler J., „Polskie miesiace” czyli kryzys(y) w PRL, Warszawa 2008.

Eisler J,, Siedmiu wspaniatych. Poczet pierwszych sekretarzy KC PZPR, Warszawa 2014. Friszke A., Czas KOR-u. Jacek Kuroń a geneza Solidarności, Kraków 2011.

Grajewski A., Kardynałowie Stefan Wyszyński i Agostino Casaroli - dwie osobowości i dwie koncepcje polityki wschodniej Watykanu, „Studia Prymasowskie” 2009 (t.3).

Gryz R., Kierunki polityki wyznaniowej w dekadzie Gierka [w:] Priorytety polityki wyznaniowej władz Polski ,„ludowej”, red. R. Łatka, ,,Glaukopis” 2015 nr 33.

Gryz R., Między liberalizacja a dezintegracja. Stosunki państwo-Kościół w latach siedemdziesiątych [w:] Stosunki państwo-Kościół w Polsce w latach 1944-2010. Studia i materiały, red. R. Łatka, Kraków 2013.

Gryz R., Pozwolić czy nie? Władze PRL wobec budownictwa katolickich obiektów sakralnych w latach 1971-1980, Kielce 2007.

Kosiński K., „Religianctwo”. Napięcie między ideologiq a religiq w świadomości członków i działaczy PZPR, „Polska 1944/45-1989. Studia i materiały” 2014 (12).

Lasota M., Wspólne drogi kardynała Karola Wojtyły i arcybiskupa Ignacego Tokarczuka, „Studia Rzeszowskie” 2003 (10).

Łatka R., Czy Prymas Polski Stefan Wyszyński był antykomunistą? [w:] Antykomunizm Polaków w XX wieku, red. P. Kardela, K. Sacewicz, Białystok-Olsztyn-Warszawa 2019. 
Łatka R., Dwie wizje roli Kościoła w realiach komunistycznej dyktatury - wymiana korespondencji pomiędzy bp. Ignacym Tokarczukiem ordynariuszem przemyskim a sekretarzem Episkopatu Polski bp. Bronisławem Dąbrowskim w 1979 r., „Dzieje Najnowsze” $2019 \mathrm{nr} 1$.

Łatka R., Episkopat Polski wobec stosunków państwo-Kościół i rzeczywistości społeczno-politycznej PRL 1970-1989, Warszawa 2019.

Łatka R., Episkopat wobec złudnej normalizacji relacji państwo-Kościót 1971-1978 [w:] Dzieje Kościoła katolickiego na Pomorzu Zachodnim w latach 1972-1978, red. M. Siedziako, Z. Stanuch, G. Wejman, Szczecin 2018.

Łatka R., Polityka władz PRL wobec Kościoła katolickiego w województwie krakowskim w latach 1980-1989, Kraków 2016.

Łatka R., Prymas Wyszyński wobec pozornej normalizacji relacji państwo-Kościół pierwszych lat rządów Edwarda Gierka (1971-1974), „Politeja” 2019 nr 60.

Łatka R., Rada Główna Episkopatu Polski a pierwsza pielgrzymka Jana Pawła II do Ojczyzny, „Dzieje Najnowsze” 2018 nr 1.

Łatka R., Rada Główna Episkopatu Polski wobec przedsierpniowej opozycji (1976-1981), „Pamięć i Sprawiedliwość” 2017, nr 1.

Łatka R., Relacje państwo-Kościót w pierwszych latach rządów Edwarda Gierka - czyli jak wyglądała polityka „normalizacji” w praktyce, [w:] Państwo-religia. Instytucje państwowe i obywatele wobec religii w Europie Środkowo-Wschodniej w XX w., tom II, red. J. Durka, Kalisz 2018.

Eatka R., The idea of the common good and the reason of state in the teaching of primate Wyszyński, „Studia Theologica Varsaviensia” 2018 nr 2.

Łatka R., Zwycięstwo Kościoła. Prymas Tysiąclecia o pierwszej papieskiej pielgrzymce po Polsce, , Biuletyn IPN” $2017 \mathrm{nr} 6$.

Łatka R., Mackiewicz B., Zamiatała D., Kardynał Stefan Wyszyński 1901-1981, Warszawa 2019.

Łeszczyński G., Początki parafii w Zbroszy Dużej, Warszawa 2007.

Maniewska K., Kościół katolicki w Bydgoszczy wobec prób laicyzacji i dezintegracji społeczeństwa w okresie rządów Edwarda Gierka (1970-1980), Warszawa 2007.

Noszczak B., My Naród. Polska i Polacy w milenijnym programie prymasa Stefana Wyszyńskiego (1956-1966/1967) [w:] Prymas Wyszyński a niepodległa. Naród-patriotyzm-państwo w nauczaniu Prymasa Tysiąclecia, red. E. K. Czaczkowska, R. Łatka, Warszawa 2019.

Micewski A., Kardynał Wyszyński, prymas i mąż stanu, Paryż 1982.

Pawlicka K., Polityka władz wobec Kościoła katolickiego (grudzień 1970-październik 1978), Warszawa 2004.

Ptaszyński R., Stommizm. Biografia polityczna Stanisława Stommy, Kraków 2018.

Raina P., 1978. Wybór papieża Jana Pawła II. Zapiski prymasa, Warszawa 2008.

Raina P., Arcybiskup Dąbrowski - rozmowy watykańskie, Warszawa 2001.

Raina P., Cele polityki władz PRL wobec Watykanu, Warszawa 2001.

Raina P., Kardynał Wyszyński. Czasy prymasowskie 1975, Warszawa 2006. 
Raina P., Kardynał Wyszyński. Czasy prymasowskie 1976, Biała Podlaska-Warszawa 2010.

Raina P., Kardynał Wyszyński. Czasy prymasowskie 1977, Warszawa-Biała Podlaska 2010.

Raina P., Kardynał Wyszyński. Czasy prymasowskie 1978, Biała Podlaska-Warszawa 2010.

Raina P., Kardynał Wyszyński, t. 1-14, Warszawa 1994-2007.

Raina P., Kardynał Wyszyński i Solidarność, Warszawa 2005.

Raina P., Sprawa obsadzenia metropolii wrocławskiej 1974-1976. Eskapady władz PRL, Pelplin 2006.

Raina P., Stefan Kardynał Wyszyński Prymas Polski, t. 1-3, Londyn 1979-1988.

Raina P., Stefan Kardynał Wyszyński. Prymas Tysiąclecia, t. 4, Warszawa 2016.

Romaniuk M. P., Życie twórczość i posługa Stefana Kardynała Wyszyńskiego Prymasa Tysiaclecia, t. 1-4, Warszawa 1994-2002.

Sasanka P., Czerwiec 1976. Geneza, przebieg, konsekwencje, Warszawa 2006.

Skibiński P., Do jakiego stopnia PRL był państwem polskim? Ocena prymasa Wyszyńskiego, [w:] Prymas Stefan Wyszyński a Niepodległa. Naród - patriotyzm - państwo w myśli i nauczaniu Prymasa Tysiąclecia, red. E. Czaczkowska, R. Łatka, Warszawa 2019.

Skibiński P., Cele polityki władz komunistycznych w Polsce wobec Stolicy Apostolskiej do roku 1978, [w:] Priorytety polityki wyznaniowej władz Polski ,ludowej”, red. R. Łatka, ,Glaukopis” 2015 nr 33.

Skórzyński J., Głodówka u św. Marcina [w:] Od Piłsudskiego do Wałęsy. Studia z dziejów Polski w XX wieku, Warszawa 2008.

Zawadka J., Wielka Nowenna w koncepcji duszpasterskiej prymasa Wyszyńskiego. Zarys problematyki pastoralno historycznej, „Warszawskie Studia Teologiczne” 2011 nr 1. Żaryn J., Dzieje Kościoła katolickiego w Polsce (1944-1989), Warszawa 2003.

Żaryn J., Kościół katolicki - hierarchia, kapłani, świeccy [w:] Między Warszawa a regionem. Opozycja przedsierpniowa na Pomorzu Zachodnim, red. M. Kowalczyk, M. Paziewski, M. Stefaniak, Szczecin 2008.

Żaryn J., Kościół katolicki w PRL - bliżej władzy czy bliżej opozycji? (1976-1981) [w:] idem, Własna i niepodległa. Czyli o Polakach walczacych o swoją Ojczyznę, Warszawa 2020.

Żaryn J., Stosunki państwo-Kościót katolicki w latach siedemdziesiątych XX w. [w:] „Oaza wolności”. Duszpasterstwa akademickie w latach siedemdziesiatych XX w., red. M. Marcinkiewicz, Szczecin 2011. 